medRxiv preprint doi: https://doi.org/10.1101/2020.05.06.20093575; this version posted May 8, 2020. The copyright holder for this preprint

(which was not certified by peer review) is the author/funder, who has granted medRxiv a license to display the preprint in perpetuity.

All rights reserved. No reuse allowed without permission.

\title{
Clinical Performance of SARS-CoV-2 Molecular Testing
}

2 Daniel A. Green, MD¹, Jason Zucker, MD4, Lars F. Westblade, $\mathrm{PhD}^{2,3}$, Susan Whittier, $\mathrm{PhD}^{1}$,

3 Hanna Rennert, $\mathrm{PhD}^{2}$, Priya Velu, $\mathrm{MD}, \mathrm{PhD}^{2}$, Arryn Craney, $\mathrm{PhD}^{2}$, Melissa Cushing, $\mathrm{MD}^{2}$,

4 Dakai Liu, PhD5, Magdalena Sobieszczyk, MD4, Amelia K. Boehme, PhD, MSPH6, Jorge L.

5 Sepulveda, MD, $\mathrm{PhD}^{1, \#}$

6

$7 \quad{ }^{1}$ Department of Pathology \& Cell Biology, Columbia University Irving Medical Center, New

8 York, NY

$9 \quad{ }^{2}$ Department of Pathology and Laboratory Medicine, Weill Cornell Medicine, New York, NY

10 3Division of Infectious Diseases, Department of Internal Medicine, Weill Cornell Medicine,

11 New York, NY

$12{ }^{4}$ Division of Infectious Diseases, Department of Internal Medicine, Columbia University

13 Irving Medical Center, New York, NY

14 5Department of Pathology and Clinical Laboratories, NewYork-Presbyterian Queens

15 Hospital

$16{ }^{6}$ Department of Epidemiology and Neurology, Columbia University Irving Medical Center,

17 New York, NY

18

19 Keywords: COVID-19, SARS-CoV-2, Sensitivity, Laboratory Utilization

NOTE: This preprint reports new research that has not been certified by peer review and should not be used to guide clinical practice. 
medRxiv preprint doi: https://doi.org/10.1101/2020.05.06.20093575; this version posted May 8, 2020. The copyright holder for this preprint (which was not certified by peer review) is the author/funder, who has granted medRxiv a license to display the preprint in perpetuity.

All rights reserved. No reuse allowed without permission.

20 Running Title: Clinical performance of COVID-19 Molecular Tests

21

22

$23{ }^{\#}$ Address correspondence to:

24 Jorge Sepulveda, MD, PhD

$25 \quad$ PH1564

$26 \quad 622 \mathrm{~W} 168 \mathrm{St}$

27 New York, NY 10032

$28 \quad 212-305-6360$

29 jls2282@cumc.columbia.edu 
medRxiv preprint doi: https://doi.org/10.1101/2020.05.06.20093575; this version posted May 8, 2020. The copyright holder for this preprint (which was not certified by peer review) is the author/funder, who has granted medRxiv a license to display the preprint in perpetuity.

All rights reserved. No reuse allowed without permission.

\section{Abstract}

32 Molecular testing for severe acute respiratory syndrome coronavirus 2 (SARS-CoV-2) is the

33 gold standard for diagnosis of coronavirus disease 2019 (COVID-19), but the test clinical

34 performance is poorly understood. From 3/10/2020-5/1/2020 NewYork-Presbyterian

35 laboratories performed 27,377 SARS-CoV-2 molecular assays from 22,338 patients. Repeat

36 testing was performed in 3,432 patients, of which 2,413 had negative and 1,019 had

37 positive first day results. Repeat-tested patients were more likely to be older, male, African-

38 American or Hispanic, and to have severe disease. Among the patients with initially

39 negative results, $18.6 \%$ became positive upon repeat-testing. Only $58.1 \%$ of any-time

40 positive patients had a result of "detected" on the first test. The clinical sensitivity of

41 COVID-19 molecular assays is estimated between $66.2 \%$ and $95.6 \%$, depending on the

42 unknown number of false negative results in single-tested patients. Conversion to a

43 negative result is unlikely to occur before 15 to 20 days after initial testing or 20-30 days

44 after the onset of symptoms, with $50 \%$ conversion occurring at 28 days after initial testing.

45 Forty-nine initially-positive patients converted to negative and then back to positive in

46 subsequent days. Conversion from first day negative to positive results increased linearly

47 with each day of testing, reaching $25 \%$ probability in 20 days. In summary, our study

48 provides estimates of the clinical performance of SARS-CoV-2 molecular assays and

49 suggests time frames for appropriate repeat testing, namely 15 to 20 days after a positive

50 test and the same or next 2 days after a negative test in a patient with high suspicion for

51 COVID-19. 
medRxiv preprint doi: https://doi.org/10.1101/2020.05.06.20093575; this version posted May 8, 2020. The copyright holder for this preprint (which was not certified by peer review) is the author/funder, who has granted medRxiv a license to display the preprint in perpetuity.

All rights reserved. No reuse allowed without permission.

\section{Introduction}

55 Coronavirus disease 2019 (COVID-19) which is caused by severe acute respiratory

56 syndrome coronavirus 2 (SARS-CoV-2) $(1,2)$ is a global pandemic with mortality

57 significantly higher than seasonal influenza (3). The rapid sequencing of SARS-CoV-2

58 genomes $(1,2)$ has allowed the development of multiple real-time reverse transcription-

59 polymerase chain reaction (RT-PCR) assays that have become the gold standard to detect

60 viral RNA and identify patients with COVID-19 as well as asymptomatic carriers. However,

61 some patients with positive chest radiologic findings and symptoms suspicious for COVID-

6219 have been reported to test negatively by SARS-CoV-2 RT-PCR and require multiple

63 consecutive tests to convert to a positive result $(4,5)$. There is limited information on the

64 clinical performance characteristics of the SARS-CoV-2 molecular tests in real world cases,

65 namely what is the predictive value of a negative result in patients suspected of COVID-19

66 and what is the relationship between the course of the disease, viral shedding, and

67 positivity of the various molecular assays. During the 2020 pandemic of COVID-19, we

68 tested 27,377 samples from 22,338 patients with SARS-CoV-2 molecular assays performed

69 at NewYork-Presbyterian (NYP) clinical laboratories. The assays used in this patient

70 population included six platforms based on reverse-transcription and nucleic acid

71 amplification to detect SARS-CoV-2 specific RNA sequences. Our goal is to identify the

72 clinical performance characteristics of SARS-CoV-2 molecular assays for diagnosis and

73 stratification of COVID-19 patients and determine the dynamics of SARS-CoV-2 molecular

74 assay results over time in a large dataset from multiple hospital locations in the New York

75 City area. 
medRxiv preprint doi: https://doi.org/10.1101/2020.05.06.20093575; this version posted May 8, 2020. The copyright holder for this preprint (which was not certified by peer review) is the author/funder, who has granted medRxiv a license to display the preprint in perpetuity.

All rights reserved. No reuse allowed without permission.

Methods

78 We extracted records of all the SARS-CoV-2 tests performed at NYP laboratories from our

79 laboratory information system (Cerner Millennium, Cerner Corporation, North Kansas City,

80 MO) using a custom Cerner Command Language query. We tested a total number of 22,338

81 patients between March 10, 2020 and May 1, 2020 for SARS-CoV-2 by molecular assays at

82 NewYork-Presbyterian affiliated hospitals and performed a total of 27,377 assays on

83 nasopharyngeal (initially also on oropharyngeal) swab samples. The vast majority of the

84 SARS-CoV-2 tests were reverse-transcription real time PCR assays performed with the

85 high-throughput automated cobas 6800 (Roche Molecular Systems, Branchburg, NJ)

86 platform $(\mathrm{N}=19,195)$, which went live at Columbia-NYP laboratory on 3/15/2020 and at

87 Cornell-NYP laboratory on 3/30/2020. A smaller number of assays were performed since

$883 / 10 / 2020$ with in-house developed tests under FDA Emergency Use Authorization using

89 the Rotor-Gene Q (N=1795, Qiagen, Valencia, CA) and 7500 Fast ( $\mathrm{N}=89$, Thermo-Fisher

90 Scientific, Waltham, MA) instruments. From 4/3/2020 thereafter other platforms were

91 introduced in the NYP laboratories, including the Xpert Xpress SARS-CoV-2 test analyzed

92 on the GeneXpert ( $=265)$ and Infinity $(\mathrm{N}=5954)$ platforms (Cepheid, Sunnyvale, $\mathrm{CA})$, the

93 ID Now (N=53), (Abbott, Chicago, IL) and the Panther Fusion (N=26) (Hologic Inc., San

94 Diego, CA) instruments. Commercial molecular viral assays were validated and performed

95 at NYP Hospital Laboratories following manufacturers' recommendations.

\section{Patients}

97 The NYP laboratory SARS-CoV-2 testing dataset contains basic demographic information

98 on each patient, including age, gender, race, and health care encounter type and location at

99 the time of order. To better understand SARS-CoV2-2 test utilization and investigate the 
medRxiv preprint doi: https://doi.org/10.1101/2020.05.06.20093575; this version posted May 8, 2020. The copyright holder for this preprint (which was not certified by peer review) is the author/funder, who has granted medRxiv a license to display the preprint in perpetuity.

All rights reserved. No reuse allowed without permission.

100 association with clinical information to the SARS-CoV-2 test results on a subset of patients,

101 we merged our laboratory dataset with the Columbia COVID-19 CARE clinical database.

102 The COVID-CARE clinical database is an interdisciplinary database, managed by the

103 Columbia Division of Infectious Diseases and contains data on all patients tested for SARS-

104 CoV-2 at the New York Presbyterian West Campus (Milstein Hospital, Allen Hospital,

105 Morgan Stanley Children's Hospital). This interdisciplinary database contains the work of

106 numerous divisions within the Departments of Medicine, Pediatrics, Neurology, and

107 Obstetrics and Gynecology. The database is comprised of a general primary instrument

108 and multiple sub-specialty instruments resulting in over 720 curated fields per patient.

109 Data was extracted from the medical record through manual review by a team of medical

110 students and sub-specialty fellows and attendings. Manually curated data is combined with

111 structured data from the electronic medical records, pharmacy, and laboratory systems to

112 complete the dataset. As of May $1^{\text {st }} 2020,1,624$ patients had undergone manual review

113 (Supplementary Table 1).

114 Clinical factors and other patient characteristic are compared between SARS-CoV-2

115 positive and SARS-CoV-2 negative patients in Supplementary Table 2, and between repeat-

116 tested and single-tested patients in Supplementary Table 3. This study was approved by

117 the Institutional Review Boards of Columbia and Cornell Universities.

119 Data Analysis

120 Categorical data was presented as frequency and percent. Continuous data was presented

121 as mean (standard deviation) or median and range. Differences between groups were

122 compared using Chi-square tests for categorical variables, and linear ANOVA for

123 continuous variables. Correction for multiple testing was performed using the false 
medRxiv preprint doi: https://doi.org/10.1101/2020.05.06.20093575; this version posted May 8, 2020. The copyright holder for this preprint (which was not certified by peer review) is the author/funder, who has granted medRxiv a license to display the preprint in perpetuity.

All rights reserved. No reuse allowed without permission.

124 discovery rate method of Benjamini-Hochberg (6). Confidence intervals for sensitivity and

125 negative predictive values were calculated using the epiR R package. Time to event using

126 Kaplan Meier curves were used to investigate time to conversion from initially negative to

127 positive and from initially positive to negative. All statistical analyses were performed

128 using the R statistical language (7).

\section{Results}

130 A total of 18,906 assays were performed once per patient and 8,471 assays were

131 performed in 3,432 (15.4\%) patients with more than one test completed in the span of 1 to

$13249($ median $=8)$ days between assays. There were 2,280 patients with multiple SARS-CoV-2

133 molecular assays performed who had a first negative, invalid, or indeterminate result and

134797 patients who had an initial positive result.

\section{Demographic and clinical characteristics}

136 Patients with any positive SARS-CoV-2 result differed from those that were never positive

137 for SARS-CoV-2 even with repeat testing (Supplementary Table 2). Notably, SARS-CoV-2

138 positive patients were more likely to be male, older than 44 years, and of self-reported

139 African-American or Hispanic / Latino ethnicity and less likely to be Asian or Caucasian

140 (Supplementary Table 2, all p<0.001). Not surprisingly, severe disease was more likely in

141 SARS-CoV-2 positive patients, as indicated by a higher fatality rate $(6.2 \% \mathrm{vs} .3 .8 \%$,

$142 \mathrm{p}=0.048)$, presence of symptoms (91.8\% vs. 72.4\%, $\mathrm{p}=0.004)$, need for intubation $(10.7 \%$

143 vs. 7\%, p=0.026) and frequency of decompensation, as defined by an outcome of

144 intubation, death, or discharge to hospice $(13.4 \%$ vs. $8.4 \%, \mathrm{p}=0.005)$.

145 To determine which factors were associated with repeat testing for SARS-CoV-2 we

146 analyzed demographic and clinical features of repeat-tested as compared to single-tested 
medRxiv preprint doi: https://doi.org/10.1101/2020.05.06.20093575; this version posted May 8, 2020. The copyright holder for this preprint (which was not certified by peer review) is the author/funder, who has granted medRxiv a license to display the preprint in perpetuity.

All rights reserved. No reuse allowed without permission.

147 patients (Supplementary Table 3). Our data show higher age (median = 59.9 vs. 53.4,

$148 \mathrm{p}<0.001)$, higher frequency of male gender (52.2\% vs. 44.3\%, p<0.001), and different

149 distribution of self-reported race and ethnicity in repeat-tested as compared to single-

150 tested patients, with African-Americans and Hispanics / Latinos being more likely to be

151 repeat-tested $(\mathrm{p}<0.001)$. At the time of the first test order, admitted patients were

152 significantly more represented in the repeat-tested population in contrast to patients

153 visiting the emergency department and outpatients $(\mathrm{p}<0.001)$. Compared with single-

154 tested patients, repeat-tested patients were 3.2 times more likely to be admitted to the ICU

155 (29.7\% vs. 9.4\%, p<0.001), 4 times more likely to be intubated $(24.4 \%$ vs. $6.1 \%, \mathrm{p}<0.001)$,

1563.4 times more likely to decompensate (27.6\% vs. 8.1\%, p<0.001) and 1.7 times more likely

157 to die during the observation period ( $8 \%$ vs. $4.7 \%, \mathrm{p}=0.038)$.

\section{SARS-CoV-2 Test Performance}

159 The characteristics of the SARS-CoV-2 tests performed in repeat-tested compared to single-

160 tested patients are described in Supplementary Table 4. The vast majority of tests were

161 performed with the cobas 6800 and the use of the various assays was not significantly

162 different between repeat and single-tested patients, except for a small number of patients

163 initially tested with the Thermo-Fisher 7500 assay, which was more likely in repeat-tested

164 patients $(\mathrm{p}<0.001$, standardized Pearson residuals for repeat-tested patients $=3.9)$.

165 Among all the repeat-tested patients, $23.2 \%$ were positive on the first test $(26.5 \%$ when

166 indeterminate results were included). If a negative test was repeated on the first day, the

167 positivity rate increased to $26.4 \%$ (29.7\% with indeterminate results). Overall positivity

168 among repeat-tested patients over the course of the study period was $39.9 \%$ in contrast to

$16949 \%$ for single-tested patients $(\mathrm{p}<0.001)$. When indeterminate results were counted as 
medRxiv preprint doi: https://doi.org/10.1101/2020.05.06.20093575; this version posted May 8, 2020. The copyright holder for this preprint (which was not certified by peer review) is the author/funder, who has granted medRxiv a license to display the preprint in perpetuity.

All rights reserved. No reuse allowed without permission.

170 positive, $42.9 \%$ of repeat-tested patients were positive over the course of the study period

171 in contrast to $50 \%$ of single-tested patients $(\mathrm{p}<0.001)$.

172 Indeterminate results are generally considered presumptive positive and occur when only

173 one of two molecular targets is detected. In our repeat-tested patients with an initial result

174 of "Indeterminate", 54.4\% ultimately had a result of "Detected", as compared to 7\% that

175 remained indeterminate upon repeat testing and $38.6 \%$ that converted to a negative status

176 during our study period, thus suggesting that it is acceptable to consider these patients

177 positive. However, it is unclear whether the initially indeterminate patients that converted

178 to negative were false positives or presented with low viral loads.

179 In contrast, a result of "Invalid" reflects the failure to amplify the built-in control and is

180 likely related to poor sampling or inadequate RNA extraction usually due to high viscosity

181 of the samples. In our study of repeat test patients, $52.7 \%$ ultimately became positive, $1.2 \%$

182 repeated as "Indeterminate" and 45.6\% repeated as 'Not Detected'. For the analysis of

183 clinical sensitivity of SARS-CoV-2 molecular tests, we considered patients with invalid

184 results as "negative", as these results can be considered clinically false negatives in the

185 sense that the patient may be infected and the test failed to yield a positive result. In

186 practice, invalid results should always be repeated, preferably with a new sample, as the

187 results are unpredictable.

188 Initial negative, invalid, or indeterminate SARS-CoV-2 test results were much more

189 frequent among repeat-tested patients (Supplementary Table 4, p<0.001) and conversely,

190 patients without a positive initial result were more likely to be repeated (21\%) than

191 initially positive patients $(8 \%, \mathrm{p}<0.001)$.

192 A subset of the cobas 6800 tests $(\mathrm{N}=5,343)$ had cycle threshold (Ct) values available for

193 analysis. The Ct represents the PCR cycle, interpolated to two decimal digits, at which the 
medRxiv preprint doi: https://doi.org/10.1101/2020.05.06.20093575; this version posted May 8, 2020. The copyright holder for this preprint (which was not certified by peer review) is the author/funder, who has granted medRxiv a license to display the preprint in perpetuity.

All rights reserved. No reuse allowed without permission.

194 real-time fluorescent signal crosses a pre-defined threshold for positivity. The Ct is

195 inversely proportional to the concentration of viral RNA. The cobas SARS-CoV-2 RT-PCR

196 assay amplifies two specific targets: Target 1 is located in the ORF1ab non-structural

197 region that is unique to SARS-CoV-2 and Target 2 is a conserved region of the structural

198 protein envelope E-gene common to all members of the Sarbecovirus sub-genus of

199 coronavirus, which include SARS-CoV-2 and SARS-CoV $(8,9)$. The cobas assay also includes

200 an internal control for assay performance that has no homology to the coronaviruses.

201 When comparing positive and indeterminate results from repeat-tested with single tested

202 patients, there were no differences in indeterminate Ct values, which is expected as by

203 definition the indeterminate results represent high Ct values. In contrast, the repeat-tested

204 group ( $\mathrm{N}=795)$ had significantly higher target $2 \mathrm{Ct}$ values (median $=29.1 \mathrm{vs.} 27.3, \mathrm{p}<0.001$

205 and frequency of target 2 Ct's above 30 (45.8\% vs. 36.9\%, p<0.001) compared to single-

206 tested patients $(\mathrm{N}=4,548)$, indicating lower viral load in the repeat-tested samples (Figure

2071 and Supplementary Table 4).

208

209 Analysis of conversion rates of repeat-tested patients

210 In this study, we classified repeat-tested patients in two groups according to their initial

211 SARS-CoV-2 results: those that were initially positive, for whom repeat testing was most

212 likely intended to ascertain recovery and non-infectiousness, and those that had an initial

213 result of negative, indeterminate, or invalid, in whom persistent clinical suspicion for

214 COVID-19 likely motivated repeat ordering of the test. Supplementary Table 4 shows the

215 different clinical characteristics between repeat-tested and single-tested patients.

216 For the time-dependent analysis of conversion rates, we considered "initially positive"

217 patients with any "Detected" or "Indeterminate" SARS-CoV-2 result obtained during the 
medRxiv preprint doi: https://doi.org/10.1101/2020.05.06.20093575; this version posted May 8, 2020. The copyright holder for this preprint (which was not certified by peer review) is the author/funder, who has granted medRxiv a license to display the preprint in perpetuity.

All rights reserved. No reuse allowed without permission.

218 first calendar day of testing rather than the first positive test, to reduce bias due to

219 nasopharyngeal sampling inadequacy (Table 1). Conversely, patients without a result of

220 "Detected" or 'Indeterminate" in the first day were labeled as "initially negative". Among

221 the 2,413 initially negative repeat-tested patients, $18.6 \%$ became positive upon repeat

222 testing on subsequent days (Supplementary Table 5), indicating a negative predictive value

223 of $81.3 \%(95 \% \mathrm{CI}=79.7$ to 82.8$)$ in this repeat-tested population with the prevalence

224 present at the time of the study.

225 In a separate analysis, we compared the results of the first test with the results from tests

226 repeated the same day (Supplementary Table 5) or repeated any time after the first result

227 (Supplementary Table 6). Among the patients with repeat testing who had initial results of

228 “Invalid” (241), “Not Detected” (2280), or “Indeterminate” (114), 4.2\% had 'Detected'

229 results upon repeat testing in the first day of testing (Supplementary Table 5). This

230 increase in positivity rate most likely results from a false-negative initial test due to pre-

231 analytic factors such as sample inadequacy, incorrect swabbing technique, or stochastic

232 sampling bias from low viral loads in the patient nasopharynx. After the first day of testing,

233 repeating invalid, negative, or indeterminate results on the same day resulted in about

$2340.8 \%$ of additional positive results per day, for a total of $18.4 \%$ positives that were missed

235 by the first test.

236 Among the 1,371 repeat-tested patients with one or more SARS-CoV-2 results of

237 "Detected", which can be assumed to be truly infected, only 58.1\% were resulted as

238 "Detected" on the initial test (Supplementary Table 5), and only $66.2 \%$ were reported as

239 "Detected" on the first day (Table 1). Considering 'Detected' and "Indeterminate" as

240 positive, 1,471 repeat-tested patients had one or more SARS-CoV-2 positive results over

241 time; only $61.9 \%$ were positive on the initial test and only $69.3 \%$ had a positive result on 
medRxiv preprint doi: https://doi.org/10.1101/2020.05.06.20093575; this version posted May 8, 2020. The copyright holder for this preprint (which was not certified by peer review) is the author/funder, who has granted medRxiv a license to display the preprint in perpetuity.

All rights reserved. No reuse allowed without permission.

242 the first day (Table 1). These data provide an estimate of the clinical sensitivity of the assay

243 in the repeat-tested population, and establish a baseline to look at conversion rates from

244 negative to positive.

245 Table 2A shows the number of patients who had an initial result of "Not Detected" on day 1

246 who converted to a SARS-CoV-2 positive status grouped per time after the initial test.

247 Conversely, Table 2B shows rates of conversion to negative for patients with a status of

248 "Detected" on day 1. Supplementary Figure 1 shows the distribution per day after onset of

249 symptoms ( $\mathbf{a}$ and $\mathbf{b}$ ) or after initial testing ( $\mathbf{c}$ to $\mathbf{f}$ ) of conversions from positive to negative

250 (left-side) and from negative to positive (right-side) in the two groups of repeat-tested

251 patients. For this analysis, positive status included "Detected" and "Indeterminate" and

252 negative status included results of "Not Detected" with "Invalid" results excluded. Among

253 the initially positive patients, the unadjusted distributions show a peak of conversion to

254 negative between 30 and 40 days after symptoms or around 20 days after initial testing.

255 Less than $10 \%$ of the patients who converted to negative converted before 15 days after

256 onset of symptoms or 10 days after initial testing. In contrast, among the patients with

257 initially negative results who converted to positive, most conversions occurred 10 days or

258 less after onset of symptoms, and in the first 1-3 days after initial testing.

259 Since we cannot be certain about the conversion rates due to a significant proportion of

260 repeat-test patients having insufficient testing performed to detect conversion (right-

261 censoring) we used a Kaplan-Meier approach to estimate the conversion rate by day of

262 testing (Figures 2, 3 and Supplementary Figure 1 e to h) with the following assumptions:

263 1. When there were multiple tests performed per patient in one day, the results

264 were aggregated to the highest result, i.e. Detected $>$ Indeterminate $>$ Not

265 Detected. 
medRxiv preprint doi: https://doi.org/10.1101/2020.05.06.20093575; this version posted May 8, 2020. The copyright holder for this preprint (which was not certified by peer review) is the author/funder, who has granted medRxiv a license to display the preprint in perpetuity.

All rights reserved. No reuse allowed without permission.

2. For initially positive patients, an event is defined as highest result in a day of "Not Detected".

3. Conversely, an event is defined as a conversion from a "Not Detected", or "Invalid" result at day 1 to "Detected" or "Indeterminate" on subsequent days. was considered right-censored at that time.

5. Only the first day and either the censoring day or the event day were used for each patient and indeterminate results were ignored.

274 The results show that the probability of converting from positive to negative in the initially

275 positive, repeat-tested population is minimal until about 15 to 20 days after initial testing

276 and reaches $50 \%$ at 28 days ( $95 \% \mathrm{CI}=27$ to 29 days, Figure 2 ). In the initially negative

277 repeat-tested population, the risk linearly increases every day with a $25 \%$ probability of

278 conversion to positive of 20 days ( $95 \% \mathrm{CI}=16$ to 23 days, Figure 3 ).

279 Since lack of conversion could be due to death of the patient, which occurred in about $8 \%$

280 of the repeat-tested population, we performed a competing risk analysis with death as the

281 alternative event, using the timereg R package (10), and did not find significant differences

282 in either the positive to negative or the negative to positive Kaplan-Meier cumulative

283 probability of conversion (results not shown).

284 Interestingly, among the repeat-tested patients we have identified 11 patients that

285 converted from an initial SARS-CoV-2 negative result to positive and back to negative over

286 several days. We also identified 49 initially positive patients that became negative and later

287 turned positive again. The time course of SARS-CoV-2 test results for these patients are

288 shown on Supplementary Figure 2. 
medRxiv preprint doi: https://doi.org/10.1101/2020.05.06.20093575; this version posted May 8, 2020. The copyright holder for this preprint (which was not certified by peer review) is the author/funder, who has granted medRxiv a license to display the preprint in perpetuity.

All rights reserved. No reuse allowed without permission.

\section{Discussion}

291 Our results from repeat-tested patients can be used to estimate the clinical sensitivity of

292 the SARS-CoV-2 molecular testing in the population of patients that were selected for

293 repeat testing, in contrast to the general population of tested patients. With all likelihood,

294 most repeat testing on initial negative patients was performed either to follow a history of

295 exposure, when the clinical profile did not fit the initial results, or when clinical

296 presentation deteriorated after the initial result. Consistent with this hypothesis, repeat-

297 tested patients were more likely to be older, male and of non-Caucasian race than single

298 tested patients (Supplementary Table 3), consistent with the demographics of COVID-19

299 positive patients (Supplementary Table 2). Importantly, repeat-tested patients had worse

300 outcomes as demonstrated by higher rates of decompensation, intubation, and mortality.

301 Interestingly, repeat-tested patient who converted from positive to negative tended to be

302 younger and present as outpatients, as compared to patients that remained positive, but

303 there were no significant differences in clinical outcomes (Supplementary Table 7). In

304 contrast, repeat-tested patients that remained negative tended to be inpatients, have

305 longer admission duration, and were more likely to be extubated than those who converted

306 to positive (Supplementary Table 8), suggesting that a significant number of repeat-testing

307 in SARS-CoV-2 negative patients was performed in inpatients admitted before the

308 pandemic or for non-COVID-19 reasons. Indeed, repeat-tested patients admitted before

309 March 1st, 2020 were much more likely to have a persistent negative result (71.4\%) than

310 those admitted after March 1st, 2020 (39.7\%, p<0.001). 
medRxiv preprint doi: https://doi.org/10.1101/2020.05.06.20093575; this version posted May 8, 2020. The copyright holder for this preprint (which was not certified by peer review) is the author/funder, who has granted medRxiv a license to display the preprint in perpetuity.

All rights reserved. No reuse allowed without permission.

311 In the absence of a more sensitive gold-standard, the repeat-tested patients with an

312 eventual positive result can be considered true positives, as the analytical specificity of

313 molecular testing is very high $(3,8,9,11,12)$. It may be tempting to add all the 9,272

314 single-tested positive patients to the 1,371 repeat-tested positive patients to determine

315 clinical sensitivity. However, we don't know how many of the "Not detected" single-tested

316 patients are false negatives, especially given the high frequency of asymptomatic or mildly

317 symptomatic COVID-19 patients (13-15). Therefore, considering only the positive patients

318 will inflate the estimated clinical sensitivity. Nevertheless, if we consider all negative

319 results (repeated or not) to be true negative (i.e. a specificity of $100 \%$ ) we can estimate the

320 upper bound of the clinical sensitivity of a first initial result to be $94.6 \%(95 \% \mathrm{CI}=94.2$ -

$32195 \%$ ). If the test is repeated on the first day to account for nasopharyngeal sampling

322 inadequacy, the upper boundary of the estimated sensitivity with these assumptions would

323 be $95.6 \%$ (95\% CI=95.2-96\%). A lower bound of clinical sensitivity can be estimated by

324 considering the worst case scenario that the same percentage of false negatives identified

325 in repeat-tested patients would apply to the general population. With these assumptions,

326 the clinical sensitivity of the SARS-CoV-2 assay can be estimated to be between $66.2 \%$

$327(95 \% \mathrm{CI}=63.6$ to 68.7$)$ and the above best case estimate of $95.6 \%$.

328 The lower clinical sensitivity of the first day results in the ultimately positive repeat-tested

329 patients suggests several possibilities:

330 1. Viral shedding increases over time in a recently infected patient and will

331 eventually cross the detection threshold in subsequent samples. This possibility

332 is suggested by the lower Ct values for target 1 and particularly target 2 on the

333 repeat-tested patients (Supplementary Table 4 and Figure 1) . 
medRxiv preprint doi: https://doi.org/10.1101/2020.05.06.20093575; this version posted May 8, 2020. The copyright holder for this preprint (which was not certified by peer review) is the author/funder, who has granted medRxiv a license to display the preprint in perpetuity.

All rights reserved. No reuse allowed without permission. one would expect longer intervals between admission and positivity due to the cohort of

2. A significant number of samples are improperly collected, and repeat testing increases the probability of detection; this is particularly likely in the first day of testing, when suspicion may be high but the initial test results were negative or inconclusive, as shown in Supplementary Table 5.

3. Initially tested patients were truly negative and acquired the infection nosocomially after admission.

The mean interval between an initial negative test result and the first positive in patients who converted in our study was 9.4 days $(95 \% \mathrm{CI}=8.4$ to 10.5 days, $\mathrm{N}=335)$, which is longer than reported by Ai et al, who showed a mean interval time between initial negative to positive RT-PCR results of $5.1 \pm 1.5$ days with a median of 4 days $(\mathrm{N}=15)(4)$. We have insufficient data to calculate incubation time as only $1.3 \%$ of the patients had symptoms after the first test, with a median time between symptoms and testing of 1.3 days. The median interval between start of symptoms and the first test in our study of 4.8 days (95\% $\mathrm{CI}=4.5$ to 5.4 days) is in line with the data from Lauer et al., who calculated a median incubation time of 5.1 days ( $95 \%$ CI $=4.5$ to 5.8 days) in patients from China (16).

The third possibility of hospital-acquired infection explaining a low rate of initial true negative result is less likely because a) patients who converted from negative to positive had shorter intervals between admission and the first test and shorter duration of admission than those who remained negative (Supplementary Table 9 and b) there were no significant differences between repeat-tested inpatients and outpatients in the average time interval between the initial negative test and the first positive test (results not shown). If there were a large number of inpatients acquiring the infection in the hospital one would expect longer intervals between admission and positivity due to the cohort of patients already admitted before the pandemic, as compared to patients recently admitted 
medRxiv preprint doi: https://doi.org/10.1101/2020.05.06.20093575; this version posted May 8, 2020. The copyright holder for this preprint (which was not certified by peer review) is the author/funder, who has granted medRxiv a license to display the preprint in perpetuity.

All rights reserved. No reuse allowed without permission.

with COVID-19. Rather, these data suggest a pattern of repeated ordering in uninfected

360 inpatients with a lower likelihood of conversion.

361 Our analysis of repeat-tested patients with an initial positive result, using the Kaplan-Meier

362 estimator, indicates that conversion to a negative result is unlikely to occur until about 15

363 to 20 days after initial testing or 20 to 30 days after start of symptoms, when the odds ratio

364 significantly increase (Figure 2 and Supplementary Figure 1). Conversely, when a patient is

365 suspected of COVID-19 but the initial test is negative, repeating the test steadily increases

366 the probably of conversion to 'Detected' every day (Figure 3). Repeat testing is especially

367 likely to yield a positive result if the initial test is indeterminate or invalid. For

368 indeterminate results, this likely reflects low levels of the virus in the sample or low viral

369 shedding in the nasopharynx early in the course of the infection. For invalid results, this

370 likely reflects sampling inadequacy, often due to excess mucous in the sample. Our finding

371 of significantly higher Ct in repeat-tested patients as compared to single-tested patients

372 supports this hypothesis.

\section{Limitations of the study}

374 This is an observational study without selection bias for the laboratory data, as all results

375 were included in the analysis. However, the clinical data was restricted to a subset of

376 patients seen at Columbia University Irving Medical Center campuses. Nevertheless, rates

377 of positivity and demographic variables captured in the laboratory dataset were not

378 significantly different between the other campuses, suggesting that the population in the

379 clinical dataset is generally representative of the New York City patients tested for COVID-

380 19. Other limitations of the study of repeat-tested patients include: 1) only 15\% of the total

381 patient's tested had repeat testing done and 2) ordering of repeat testing was at the

382 discretion of the health care providers and not performed according to a standard protocol, 
medRxiv preprint doi: https://doi.org/10.1101/2020.05.06.20093575; this version posted May 8, 2020. The copyright holder for this preprint (which was not certified by peer review) is the author/funder, who has granted medRxiv a license to display the preprint in perpetuity.

All rights reserved. No reuse allowed without permission.

383 although test ordering was mostly accomplished through standardized electronic medical

384 record order sets.

385 Conclusions

386 Our data suggest that patients with a high clinical suspicion or exposure setting suggestive

387 of COVID-19 should be tested by a molecular SARS-CoV-2 assay and it is appropriate to

388 repeat the test the same day or in subsequent days if the results are initially negative.

389 Conversely, for patients with a positive SARS-CoV-2 molecular assay result, repeating the

390 test before at least 15 days after the first test is unlikely to yield a negative result. Whether

391 repeat positivity represents active infection or detection of nonviable viral RNA is

392 unknown. Further studies are needed to develop predictive models of the course and

393 outcomes of COVID-19 using well-curated demographic, clinical, and laboratory datasets.

396 Acknowledgments:

397 We would like to acknowledge the contributions of all the dedicated medical technologists

398 and laboratory technicians who performed testing at NYP laboratories, the efforts of the

399 NYP Laboratory Information Team, in particular Kelvin Espinal, Sarah Russell, Dennis

400 Camp, Yingzhe Kuang, and Bulent Oral for designing queries and providing data extracts,

401 and the volunteers who helped gather data from electronic medical records for the COVID-

40219 CARE database.

403 Funding: This research received no specific grant from any funding agency in the public, 404 commercial, or not-for-profit sectors. 
medRxiv preprint doi: https://doi.org/10.1101/2020.05.06.20093575; this version posted May 8, 2020. The copyright holder for this preprint (which was not certified by peer review) is the author/funder, who has granted medRxiv a license to display the preprint in perpetuity.

405 Potential conflicts of interest All authors have no conflicts.

\section{$\underline{\text { References }}$}

409 1. Wu F, Zhao S, Yu B, Chen Y-M, Wang W, Song Z-G, Hu Y, Tao Z-W, Tian J-H, Pei Y-Y, Yuan

410 M-L, Zhang Y-L, Dai F-H, Liu Y, Wang Q-M, Zheng J-J, Xu L, Holmes EC, Zhang Y-Z. 2020.

411 A new coronavirus associated with human respiratory disease in China. 7798. Nature

$412 \quad 579: 265-269$.

413 2. Zhu N, Zhang D, Wang W, Li X, Yang B, Song J, Zhao X, Huang B, Shi W, Lu R, Niu P, Zhan

414 F, Ma X, Wang D, Xu W, Wu G, Gao GF, Tan W. 2020. A Novel Coronavirus from Patients

415 with Pneumonia in China, 2019. N Engl J Med 382:727-733.

416 3. Zhou F, Yu T, Du R, Fan G, Liu Y, Liu Z, Xiang J, Wang Y, Song B, Gu X, Guan L, Wei Y, Li H,

417 Wu X, Xu J, Tu S, Zhang Y, Chen H, Cao B. 2020. Clinical course and risk factors for

418 mortality of adult inpatients with COVID-19 in Wuhan, China: a retrospective cohort

419 study. Lancet 395:1054-1062.

420 4. Ai T, Yang Z, Hou H, Zhan C, Chen C, Lv W, Tao Q, Sun Z, Xia L. 2020. Correlation of Chest

421 CT and RT-PCR Testing in Coronavirus Disease 2019 (COVID-19) in China: A Report of

4221014 Cases. Radiology 200642.

423 5. Xie X, Zhong Z, Zhao W, Zheng C, Wang F, Liu J. 2020. Chest CT for Typical 2019-nCoV

424 Pneumonia: Relationship to Negative RT-PCR Testing. Radiology 200343. 
medRxiv preprint doi: https://doi.org/10.1101/2020.05.06.20093575; this version posted May 8, 2020. The copyright holder for this preprint (which was not certified by peer review) is the author/funder, who has granted medRxiv a license to display the preprint in perpetuity. All rights reserved. No reuse allowed without permission.

6. Benjamini Y, Hochberg Y. 1995. Controlling the False Discovery Rate: A Practical and Powerful Approach to Multiple Testing. Journal of the Royal Statistical Society: Series B

7. R Core Team. 2017. R: A Language and Environment for Statistical Computing.

8. Pfefferle S, Reucher S, Nörz D, Lütgehetmann M. 2020. Evaluation of a quantitative RTPCR assay for the detection of the emerging coronavirus SARS-CoV-2 using a high Xpress and Abbott ID Now to Roche cobas for the Rapid Detection of SARS-CoV-2. bioRxiv 2020.04.22.055327.

10. Scheike TH, Zhang M-J. 2011. Analyzing Competing Risk Data Using the R timereg Package. 1. Journal of Statistical Software 38:1-15.

11. Cordes AK, Heim A. 2020. Rapid random access detection of the novel SARScoronavirus-2 (SARS-CoV-2, previously 2019-nCoV) using an open access protocol for the Panther Fusion. J Clin Virol 125:104305. Sample-To-Answer Platforms for the Detection of SARS-CoV-2. J Clin Microbiol.

442 13. Lai C-C, Liu YH, Wang C-Y, Wang Y-H, Hsueh S-C, Yen M-Y, Ko W-C, Hsueh P-R. 2020. 443 Asymptomatic carrier state, acute respiratory disease, and pneumonia due to severe 444 acute respiratory syndrome coronavirus 2 (SARS-CoV-2): Facts and myths. J Microbiol $445 \quad$ Immunol Infect. 
medRxiv preprint doi: https://doi.org/10.1101/2020.05.06.20093575; this version posted May 8, 2020. The copyright holder for this preprint

(which was not certified by peer review) is the author/funder, who has granted medRxiv a license to display the preprint in perpetuity.

All rights reserved. No reuse allowed without permission.

446 14. Li C, Ji F, Wang L, Wang L, Hao J, Dai M, Liu Y, Pan X, Fu J, Li L, Yang G, Yang J, Yan X, Gu

447 B. Early Release - Asymptomatic and Human-to-Human Transmission of SARS-CoV-2 in

448 a 2-Family Cluster, Xuzhou, China - Volume 26, Number 7-July 2020 - Emerging

449 Infectious Diseases journal - CDC.

450 15. Wang Y, Liu Y, Liu L, Wang X, Luo N, Li L. Clinical Outcomes in 55 Patients With Severe

451 Acute Respiratory Syndrome Coronavirus 2 Who Were Asymptomatic at Hospital

452 Admission in Shenzhen, China. J Infect Dis.

453 16. Lauer SA, Grantz KH, Bi Q, Jones FK, Zheng Q, Meredith HR, Azman AS, Reich NG, Lessler

454 J. 2020. The Incubation Period of Coronavirus Disease 2019 (COVID-19) From Publicly

455 Reported Confirmed Cases: Estimation and Application. Ann Intern Med.

456

457

458

459 
medRxiv preprint doi: https://doi.org/10.1101/2020.05.06.20093575; this version posted May 8, 2020. The copyright holder for this preprint (which was not certified by peer review) is the author/funder, who has granted medRxiv a license to display the preprint in perpetuity.

All rights reserved. No reuse allowed without permission.

\section{Tables}

461 Table 1: Number of SARS-CoV-2 molecular test results over the course of repeat testing,

462 grouped by the highest test result on day 1.

\begin{tabular}{lrrrrr}
\hline $\begin{array}{l}\text { Highest Result } \\
\text { Any Day } \rightarrow\end{array}$ & Invalid & Not Detected & Indeterminate & Detected & Total \\
Highest Day 1 & & & $(\mathrm{N}=1)$ & $(\mathrm{N}=1960)$ & $\mathrm{p}$ value <0.0011 \\
Result & & & & & \\
Invalid & $1(100 \%)$ & $80(4.1 \%)$ & $3(3.0 \%)$ & $79(5.8 \%)$ & $163(4.7 \%)$ \\
Not Detected & $0(0.0 \%)$ & $1880(95.9 \%)$ & $35(35.0 \%)$ & $335(24.4 \%)$ & $2250(65.6 \%)$ \\
Indeterminate & $0(0.0 \%)$ & $0(0.0 \%)$ & $62(62.0 \%)$ & $50(3.6 \%)$ & $112(3.3 \%)$ \\
Detected & $0(0.0 \%)$ & $0(0.0 \%)$ & $0(0.0 \%)$ & $907(66.2 \%)$ & $907(26.4 \%)$
\end{tabular}

463 1. Pearson's Chi-squared test (adjusted for multiple comparisons)

464

465 
medRxiv preprint doi: https://doi.org/10.1101/2020.05.06.20093575; this version posted May 8, 2020. The copyright holder for this preprint (which was not certified by peer review) is the author/funder, who has granted medRxiv a license to display the preprint in perpetuity.

All rights reserved. No reuse allowed without permission.

466 Table 2: Distribution of repeat tests per day after a first day result of "Not Detected" or

467 “Indeterminate" (A) or after a first day result of "Detected” (B).

Not Detected Indeterminate Detected Total

\section{Day of testing}

\section{A. Highest day 1 result of "Not Detected" or "Indeterminate"}

\begin{tabular}{lrccr}
\hline 1 & $1995(95.2 \%)$ & $100(4.8 \%)$ & $0(0.0 \%)$ & 2095 \\
2 & $505(75.6 \%)$ & $38(5.7 \%)$ & $125(18.7 \%)$ & 668 \\
$3-6$ & $568(84.6 \%)$ & $7(1.0 \%)$ & $96(14.3 \%)$ & 671 \\
$7-9$ & $322(89.4 \%)$ & $5(1.4 \%)$ & $33(9.2 \%)$ & 360 \\
$10-16$ & $464(86.6 \%)$ & $5(0.9 \%)$ & $67(12.5 \%)$ & 536 \\
$>16$ & $562(85.3 \%)$ & $7(1.1 \%)$ & $90(13.7 \%)$ & 659
\end{tabular}

B. Highest day 1 result of 'Detected"

\begin{tabular}{lrclr}
\hline 1 & $0(0.0 \%)$ & $0(0.0 \%)$ & $754(100 \%)$ & 754 \\
2 & $5(13.5 \%)$ & $2(5.4 \%)$ & $30(81.1 \%)$ & 37 \\
$3-6$ & $7(14.3 \%)$ & $1(2.0 \%)$ & $41(83.7 \%)$ & 49 \\
$7-9$ & $12(16.7 \%)$ & $6(8.3 \%)$ & $54(75.0 \%)$ & 210 \\
$10-16$ & $43(20.5 \%)$ & $19(9.0 \%)$ & $148(70.5 \%)$ & 221 \\
$16-20$ & $196(88.7 \%)$ & $2(0.9 \%)$ & $23(10.4 \%)$ & 269 \\
$21-30$ & $227(84.4 \%)$ & $0(0.0 \%)$ & $42(15.6 \%)$ & 169 \\
$>30$ & $139(82.2 \%)$ & $5(3.0 \%)$ & $25(14.8 \%)$ &
\end{tabular}


medRxiv preprint doi: https://doi.org/10.1101/2020.05.06.20093575; this version posted May 8, 2020. The copyright holder for this preprint (which was not certified by peer review) is the author/funder, who has granted medRxiv a license to display the preprint in perpetuity.

All rights reserved. No reuse allowed without permission.

\section{Figure Legends}

470 Figure 1: Density distribution of cobas SARS-2-CoV2 Target 2 Ct values in repeat-tested

471 vs. single-tested patients. Top panel: Ct values from results reported as "Intermediate";

472 bottom panel: Ct values from results reported as "Detected".

473

474 Figure 2: Kaplan-Meier estimate of conversion from an initially positive SARS-CoV-2 status

475 on day 1 to a subsequent negative result.

476

477 Figure 3: Kaplan-Meier estimate of conversion rate from initially negative SARS-CoV-2

478 status on day 1 to a subsequent positive result. 
medRxiv preprint doi: https://doi.org/10.1101/2020.05.06.20093575; this version posted May 8, 2020. The copyright holder for this preprint (which was not certified by peer review) is the author/funder, who has granted medRxiv a license to display the preprint in perpetuity. All rights reserved. No reuse allowed without permission.

Figure 1: Density distribution of cobas SARS-2-CoV2 Target 2 Ct in repeat-tested vs. singletested patients. Top panel: Ct values from results reported as "intermediate"; bottom panel: Ct values from results reported as "detected".

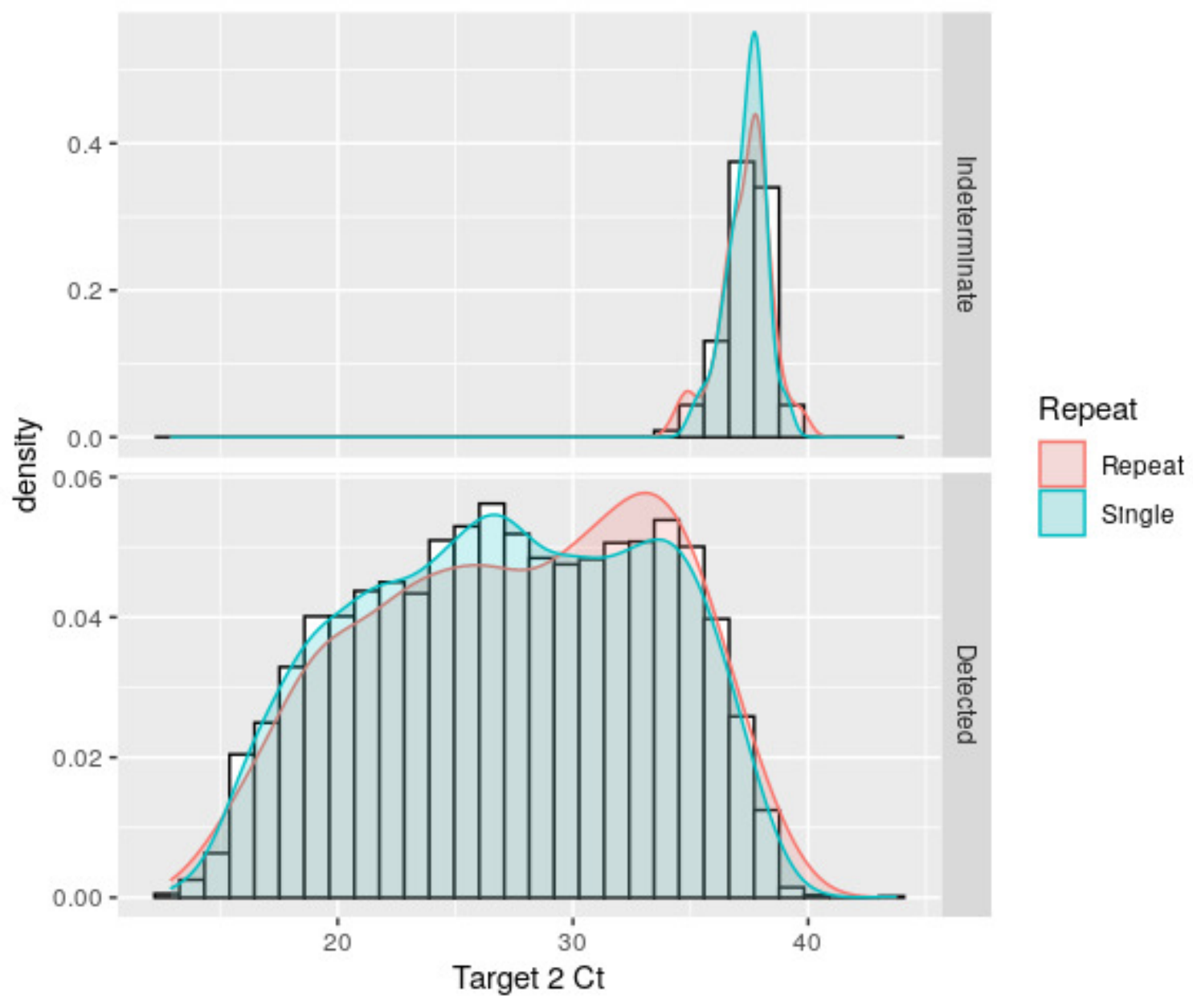


medRxiv preprint doi: https://doi.org/10.1101/2020.05.06.20093575; this version posted May 8, 2020. The copyright holder for this preprint (which was not certified by peer review) is the author/funder, who has granted medRxiv a license to display the preprint in perpetuity.

All rights reserved. No reuse allowed without permission.

Figure 2: Kaplan-Meier estimate of conversion from an initially positive SARS-CoV-2 status on day 1 to a subsequent negative result.

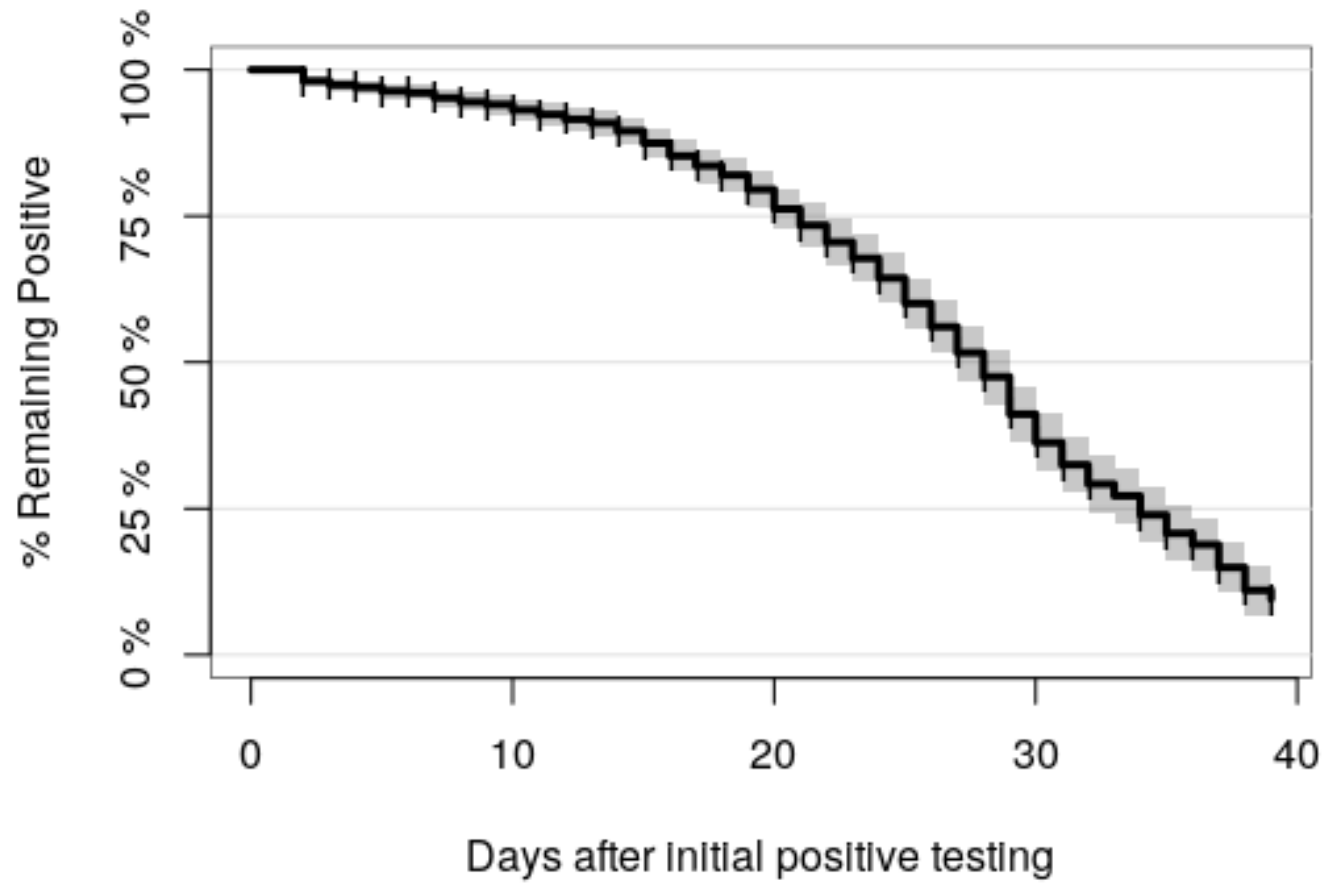

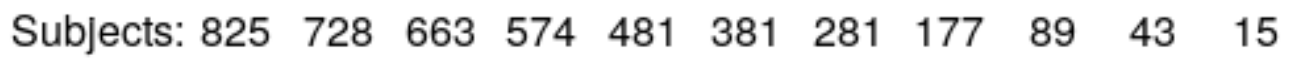

Figure 3: Kaplan-Meier estimate of conversion rate from initially negative SARS-CoV-2 status on day 1 to a subsequent positive result.

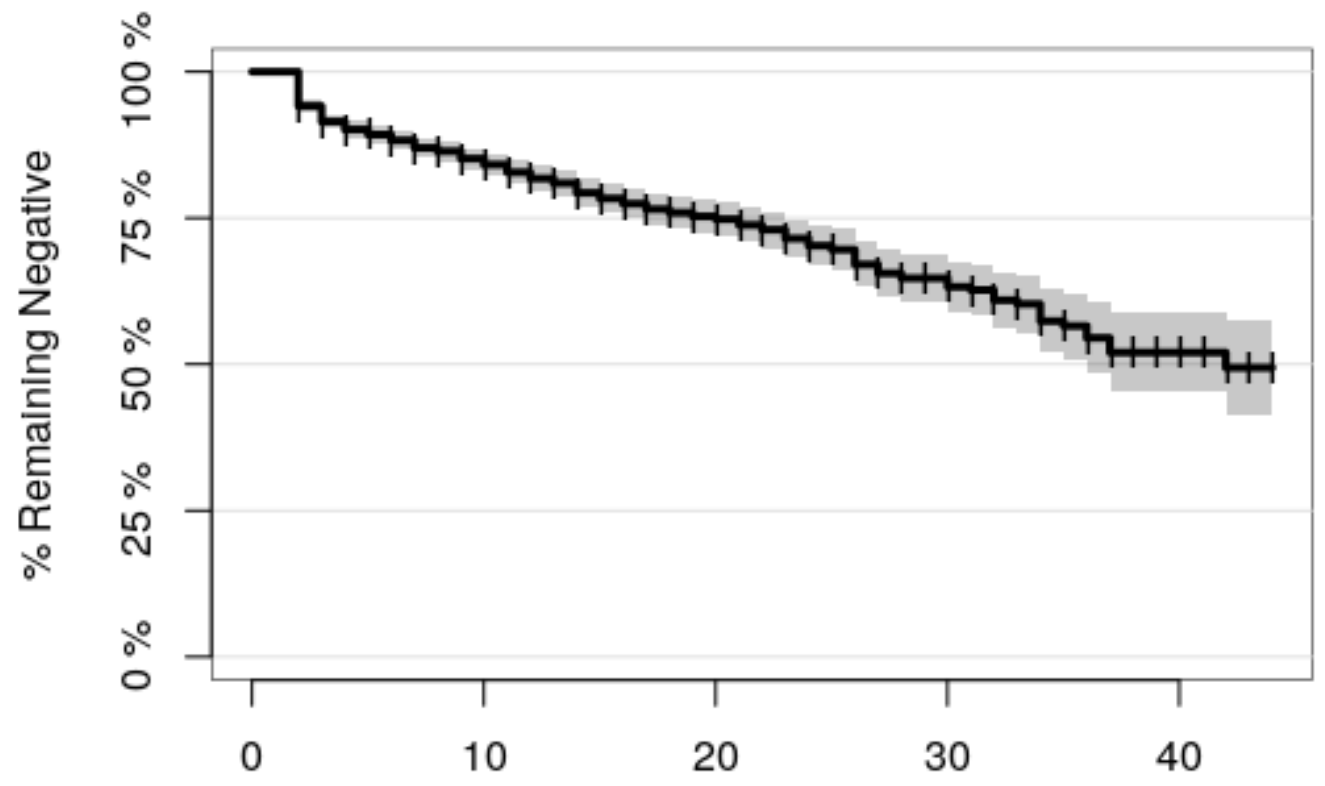

Days after Inltial negative testing

Subjects:19761160 $822545 \quad 379272 \quad 176 \quad 116 \quad 55 \quad 27 \quad 13$ 
medRxiv preprint doi: https://doi.org/10.1101/2020.05.06.20093575; this version posted May 8, 2020. The copyright holder for this preprint (which was not certified by peer review) is the author/funder, who has granted medRxiv a license to display the preprint in perpetuity.

All rights reserved. No reuse allowed without permission.

Supplementary Figure 1: Conversion distributions for repeat-tested patients with initial SARS-CoV-2 negative (a, c, e, and $\mathbf{g}$ ) and positive (b, d, f, and $\mathbf{h}$ ) results. For the analyses in a to $\mathbf{d}$ only the first conversion events (i.e. negative to positive - $\mathbf{a}$ and $\mathbf{c}$ - or positive to negative - $\mathbf{b}$ and $\mathbf{d}$ ) were considered. $\mathbf{N}$ represents the total numbers of patients analyzed. The distributions in a to $\mathbf{d}$ are represented by density-adjusted histograms (in grey bars), kernel probability density lines (in blue), unadjusted cumulative distributions (red line) and Kaplan-Meier hazard rates (green); the timing of individual results are represented by the black marks along the x-axis. For the Kaplan Meier estimated hazard rates ( $\mathbf{e}$ to $\mathbf{h}$ ), in addition to the conversion events, patients were considered censored at the time of the last unchanged result were included and the number of patients at risk for conversion at each time point are shown in $\mathbf{g}$ and $\mathbf{h}$. 
medRxiv preprint doi: https://doi.org/10.1101/2020.05.06.20093575; this version posted May 8, 2020. The copyright holder for this preprint (which was not certified by peer review) is the author/funder, who has granted medRxiv a license to display the preprint in perpetuity.

a

\section{Converslon to Negative In Patlents InItlally Positive}

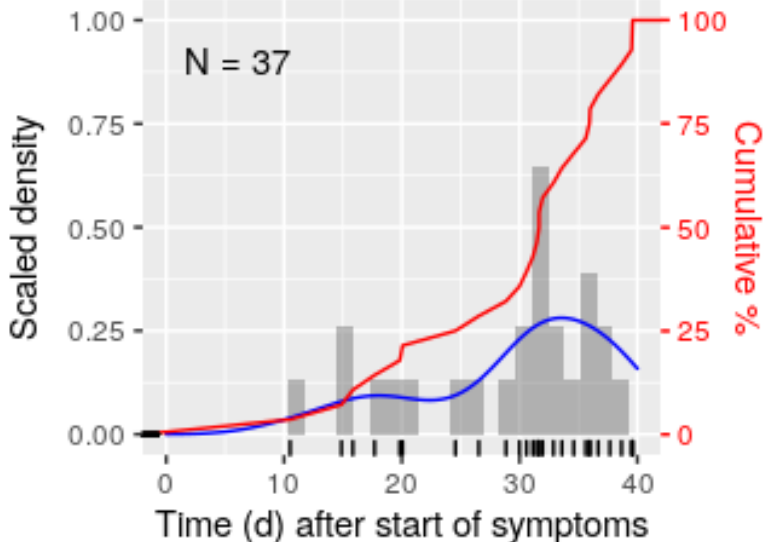

C

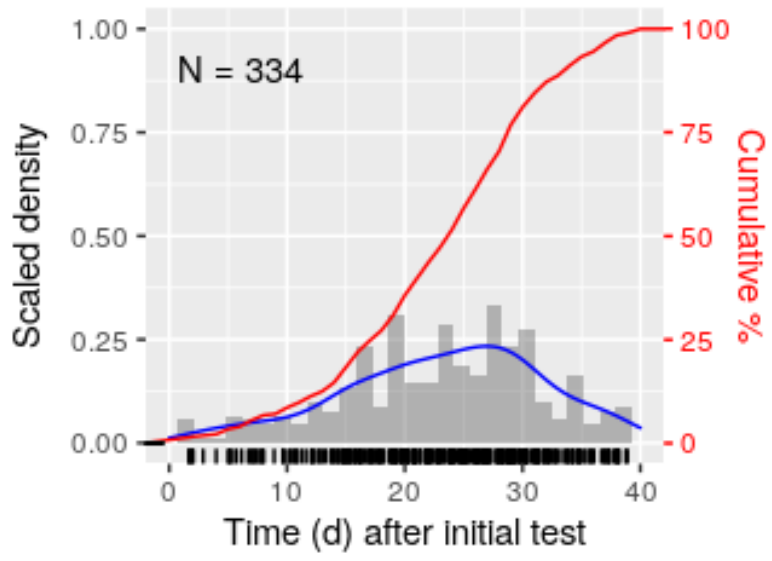

e

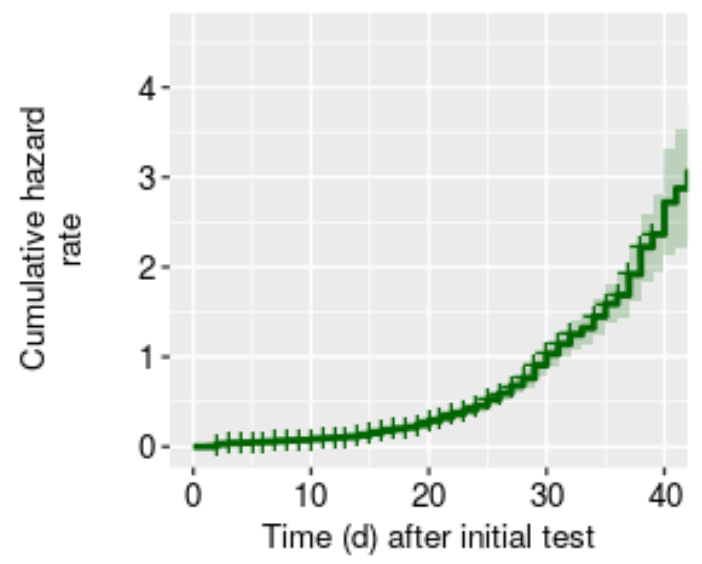

g

\section{b Conversion to Positlve In Patlents Inltlally Negatlve}

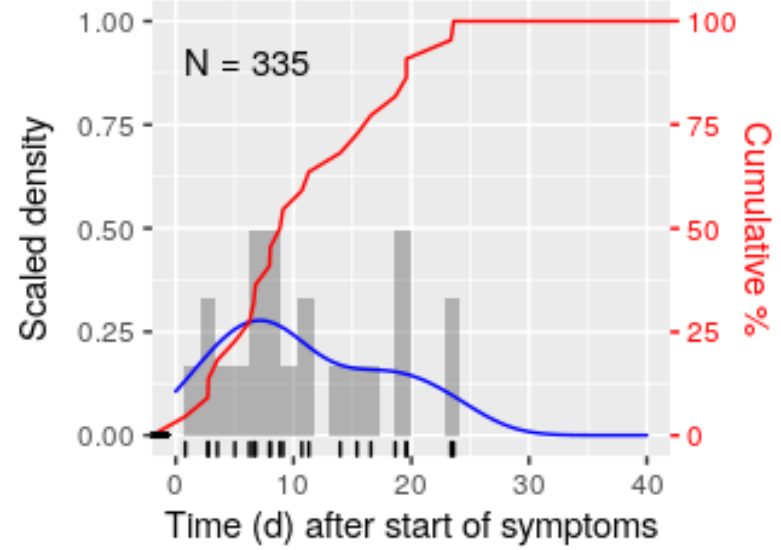

d

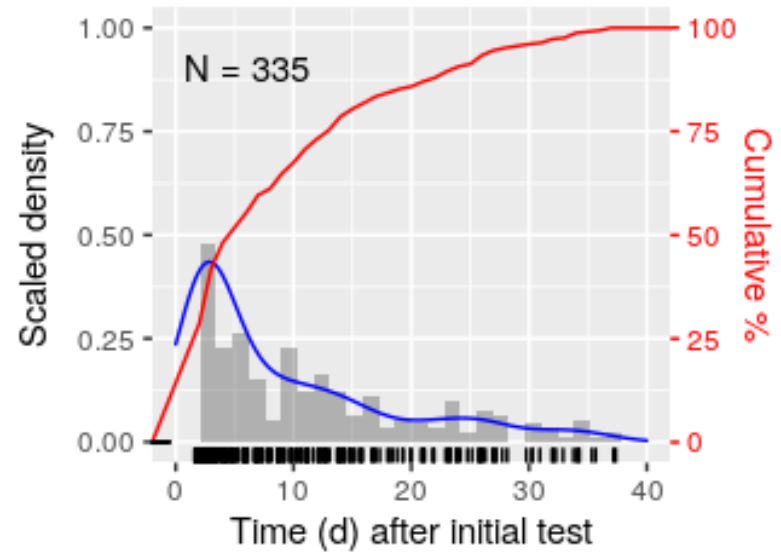

f

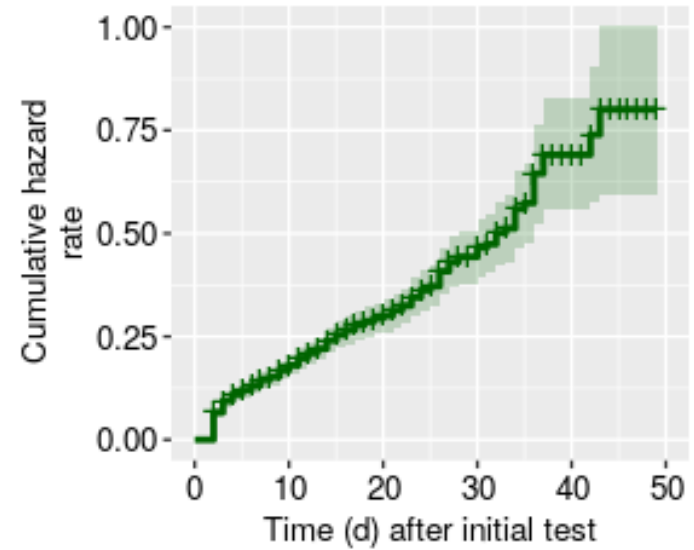

h

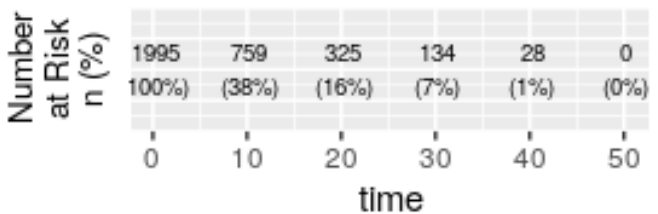


medRxiv preprint doi: https://doi.org/10.1101/2020.05.06.20093575; this version posted May 8, 2020. The copyright holder for this preprint (which was not certified by peer review) is the author/funder, who has granted medRxiv a license to display the preprint in perpetuity.

All rights reserved. No reuse allowed without permission.

Supplementary Figure 2: SARS-CoV-2 results from repeat-tested patients that converted from negative to positive and back to negative (A) or from positive to negative and back to positive (B). SARS-CoV-2 negative results are represented by blue dots and positive results are in red, plotted on a time scale from the date of the first test

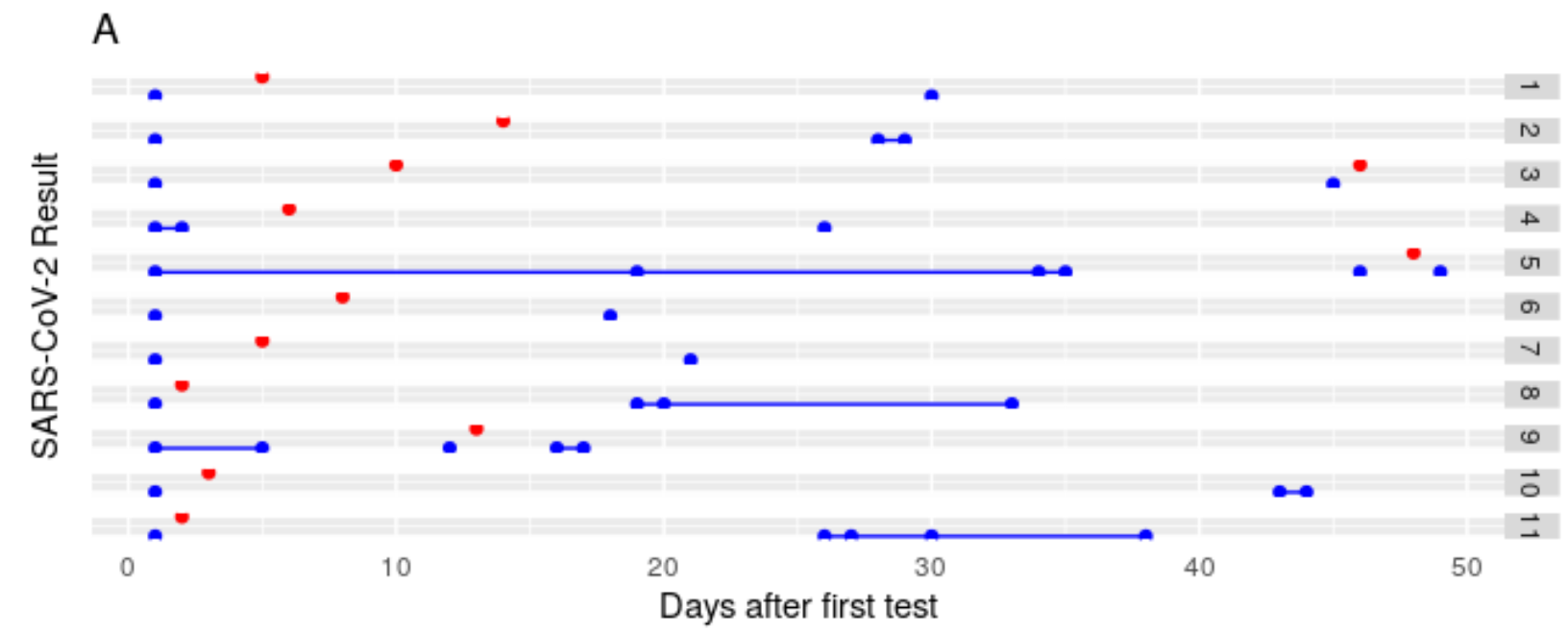


medRxiv preprint doi: https://doi.org/10.1101/2020.05.06.20093575; this version posted May 8, 2020. The copyright holder for this preprint (which was not certified by peer review) is the author/funder, who has granted medRxiv a license to display the preprint in perpetuity.

All rights reserved. No reuse allowed without permission.

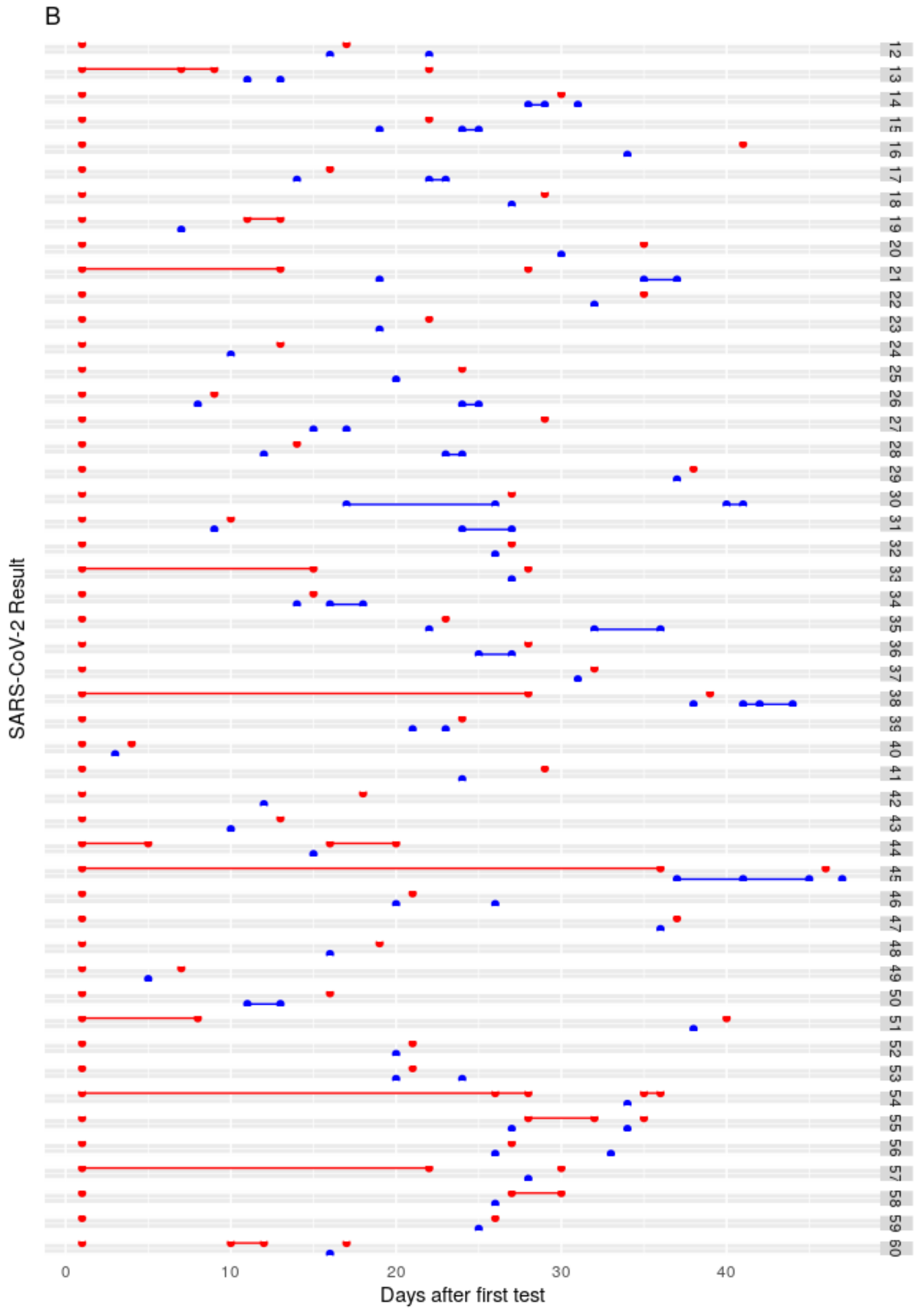


medRxiv preprint doi: https://doi.org/10.1101/2020.05.06.20093575; this version posted May 8, 2020. The copyright holder for this preprint (which was not certified by peer review) is the author/funder, who has granted medRxiv a license to display the preprint in perpetuity.

All rights reserved. No reuse allowed without permission.

\section{Supplementary Tables}

Supplementary Table 1: Numbers of unique patients in the Columbia Clinical COVID-19 dataset, NYP Laboratory SARS-CoV-2 Testing dataset, and the merged dataset.

\begin{tabular}{rrrr}
\hline Unique Patients & Merged dataset & Laboratory dataset only & Clinical dataset only \\
\hline Total & 1588 & 20750 & 36 \\
SARS-CoV-2 Positive & 990 & 9653 & 11 \\
Repeat-tested & 275 & 3157 & 0 \\
With symptoms & 529 & 0 & 8 \\
Deceased & 84 & 0 & 0 \\
\hline SARS-CoV-2 Tests & & & 2 \\
Total & 2023 & 25354 & 4 \\
SARS-CoV-2 Positive & 1266 & 11454 & 0 \\
Repeat-tested & 710 & 7761 & 1 \\
With symptoms & 707 & 0 & 0
\end{tabular}


Supplementary Table 2: Patient characteristics, grouped by highest SARS-2-CoV2 result in each patient. Negative indicates a result of "Not Detected" and Positive includes results reported as "Detected" or "Indeterminate". Time-dependent clinical factors, such as age group, symptom start to test interval, and encounter type at time of test order, are counted at the time of the first test.

\begin{tabular}{|c|c|c|c|c|}
\hline & $\begin{array}{r}\text { Negative } \\
(\mathrm{N}=11352)\end{array}$ & Positive (N=10920) & Total $(\mathrm{N}=22272)$ & $\mathrm{p}$ value \\
\hline Gender at birth & & & & $<0.0011$ \\
\hline Female & $\begin{array}{r}7045 \\
(62.1 \%)\end{array}$ & $5061(46.4 \%)$ & $12106(54.4 \%)$ & \\
\hline Male & $\begin{array}{r}4291 \\
(37.8 \%)\end{array}$ & $5851(53.6 \%)$ & $10142(45.5 \%)$ & \\
\hline Unknown & $16(0.1 \%)$ & $7(0.1 \%)$ & $23(0.1 \%)$ & \\
\hline $\mathrm{N}$ & 11352 & 10919 & 22271 & \\
\hline Age at order & & & & $<0.001^{2}$ \\
\hline Median & 42.9 & 61.5 & 54.4 & \\
\hline Mean (sd) & $46.5(23.0)$ & $60.0(19.3)$ & $53.1(22.3)$ & \\
\hline Q1, Q3 & $31.4,64.0$ & $46.5,74.5$ & $35.5,70.4$ & \\
\hline Range & $0.0-120.3$ & $0.0-144.7$ & $0.0-144.7$ & \\
\hline $\mathrm{N}$ & 11352 & 10920 & 22272 & \\
\hline Age group (y) & & & & $<0.001^{3}$ \\
\hline $0-19$ & $1069(9.4 \%)$ & $155(1.4 \%)$ & $1224(5.5 \%)$ & \\
\hline $20-44$ & $\begin{array}{r}4912 \\
(43.3 \%)\end{array}$ & $2387(21.9 \%)$ & $7299(32.8 \%)$ & \\
\hline $45-54$ & $\begin{array}{r}1255 \\
(11.1 \%)\end{array}$ & $1533(14.0 \%)$ & $2788(12.5 \%)$ & \\
\hline $55-64$ & $\begin{array}{r}1389 \\
(12.2 \%)\end{array}$ & $2148(19.7 \%)$ & $3537(15.9 \%)$ & \\
\hline $65-74$ & $\begin{array}{r}1236 \\
(10.9 \%)\end{array}$ & $2065(18.9 \%)$ & $3301(14.8 \%)$ & \\
\hline $75-84$ & $868(7.7 \%)$ & $1588(14.5 \%)$ & $2456(11.0 \%)$ & \\
\hline$>=85$ & $616(5.4 \%)$ & $1044(9.6 \%)$ & $1660(7.5 \%)$ & \\
\hline $\mathrm{N}$ & 11345 & 10920 & 22265 & \\
\hline Ethnicity & & & & $<\left(0.001^{1}\right.$ \\
\hline Hispanic/Latino & $154(26.3 \%)$ & $308(31.0 \%)$ & $462(29.3 \%)$ & \\
\hline Not Hispanic/Latino & $311(53.2 \%)$ & $409(41.2 \%)$ & $720(45.7 \%)$ & \\
\hline Not Specified & $120(20.5 \%)$ & $275(27.7 \%)$ & $395(25.0 \%)$ & \\
\hline $\mathrm{N}$ & 585 & 992 & 1577 & \\
\hline Race & & & & $<0.001^{1}$ \\
\hline Asian & $752(6.6 \%)$ & $531(4.9 \%)$ & $1283(5.8 \%)$ & \\
\hline Black or African American & $\begin{array}{r}1629 \\
(14.3 \%)\end{array}$ & $1833(16.8 \%)$ & $3462(15.5 \%)$ & \\
\hline Caucasian & $\begin{array}{r}3586 \\
(31.6 \%)\end{array}$ & $2356(21.6 \%)$ & $5942(26.7 \%)$ & \\
\hline
\end{tabular}


medRxiv preprint doi: https://doi.org/10.1101/2020.05.06.20093575; this version posted May 8, 2020. The copyright holder for this preprint (which was not certified by peer review) is the author/funder, who has granted medRxiv a license to display the preprint in perpetuity. All rights reserved. No reuse allowed without permission.

\begin{tabular}{|c|c|c|c|c|}
\hline & $\begin{array}{r}\text { Negative } \\
(\mathrm{N}=11352)\end{array}$ & Positive $(\mathrm{N}=10920)$ & Total $(\mathrm{N}=22272)$ & $\mathrm{p}$ value \\
\hline Declined & $\begin{array}{r}1593 \\
(14.0 \%)\end{array}$ & $1308(12.0 \%)$ & $2901(13.0 \%)$ & \\
\hline Other & $\begin{array}{r}1769 \\
(15.6 \%)\end{array}$ & $2287(20.9 \%)$ & $4056(18.2 \%)$ & \\
\hline Pacific Islander & $20(0.2 \%)$ & $25(0.2 \%)$ & $45(0.2 \%)$ & \\
\hline Unavailable & $\begin{array}{r}2003 \\
(17.6 \%)\end{array}$ & $2580(23.6 \%)$ & $4583(20.6 \%)$ & \\
\hline $\mathrm{N}$ & 11352 & 10920 & 22272 & \\
\hline Highest level of care & & & & $0.025^{1}$ \\
\hline Admitted & $229(41.4 \%)$ & $305(35.1 \%)$ & $534(37.6 \%)$ & \\
\hline Discharged from ED & $58(10.5 \%)$ & $71(8.2 \%)$ & $129(9.1 \%)$ & \\
\hline ICU-level Care & $69(12.5 \%)$ & $119(13.7 \%)$ & $188(13.2 \%)$ & \\
\hline Outpatient & 197 (35.6\%) & $373(43.0 \%)$ & $570(40.1 \%)$ & \\
\hline $\mathrm{N}$ & 553 & 868 & 1421 & \\
\hline Encounter type at order & & & & $<0.001^{1}$ \\
\hline Emergency & $\begin{array}{r}2706 \\
(23.8 \%)\end{array}$ & $4748(43.5 \%)$ & $7454(33.5 \%)$ & \\
\hline Inpatient & $\begin{array}{r}3827 \\
(33.7 \%)\end{array}$ & $2555(23.4 \%)$ & $6382(28.7 \%)$ & \\
\hline Outpatient & $\begin{array}{r}4819 \\
(42.5 \%)\end{array}$ & $3617(33.1 \%)$ & $8436(37.9 \%)$ & \\
\hline $\mathrm{N}$ & 11352 & 10920 & 22272 & \\
\hline Location at order & & & & $<0.0011$ \\
\hline Allen Hospital & $448(3.9 \%)$ & $845(7.7 \%)$ & $1293(5.8 \%)$ & \\
\hline Columbia & $\begin{array}{r}4505 \\
(39.7 \%)\end{array}$ & $3924(35.9 \%)$ & $8429(37.8 \%)$ & \\
\hline Columbia Outreach & $509(4.5 \%)$ & $743(6.8 \%)$ & $1252(5.6 \%)$ & \\
\hline Lower Manhattan & $633(5.6 \%)$ & $437(4.0 \%)$ & $1070(4.8 \%)$ & \\
\hline Queens & $\begin{array}{r}1588 \\
(14.0 \%)\end{array}$ & $2555(23.4 \%)$ & $4143(18.6 \%)$ & \\
\hline Weill Cornell & $\begin{array}{r}3518 \\
(31.0 \%)\end{array}$ & $2388(21.9 \%)$ & $5906(26.5 \%)$ & \\
\hline Westchester & $151(1.3 \%)$ & $28(0.3 \%)$ & $179(0.8 \%)$ & \\
\hline $\mathrm{N}$ & 11352 & 10920 & 22272 & \\
\hline Number of admissions & & & & $0.008^{2}$ \\
\hline Median & 1.0 & 0.0 & 0.0 & \\
\hline Mean (sd) & $0.5(0.5)$ & $0.5(0.5)$ & $0.5(0.5)$ & \\
\hline Q1, Q3 & $0.0,1.0$ & $0.0,1.0$ & $0.0,1.0$ & \\
\hline Range & $0.0-2.0$ & $0.0-2.0$ & $0.0-2.0$ & \\
\hline $\mathrm{N}$ & 584 & 995 & 1579 & \\
\hline Admission duration (d) & & & & $0.046^{2}$ \\
\hline
\end{tabular}


medRxiv preprint doi: https://doi.org/10.1101/2020.05.06.20093575; this version posted May 8, 2020. The copyright holder for this preprint (which was not certified by peer review) is the author/funder, who has granted medRxiv a license to display the preprint in perpetuity. All rights reserved. No reuse allowed without permission.

\begin{tabular}{|c|c|c|c|c|}
\hline & $\begin{array}{r}\text { Negative } \\
(\mathrm{N}=11352)\end{array}$ & Positive (N=10920) & Total $(\mathrm{N}=22272)$ & $\mathrm{p}$ value \\
\hline Median & 1.0 & 0.6 & 0.7 & \\
\hline Mean (sd) & $5.7(13.9)$ & $4.5(8.1)$ & $4.9(10.6)$ & \\
\hline Q1, Q3 & $0.4,4.0$ & $0.3,4.9$ & $0.3,4.5$ & \\
\hline Range & $0.0-139.0$ & $0.0-82.2$ & $0.0-139.0$ & \\
\hline $\mathrm{N}$ & 584 & 995 & 1579 & \\
\hline Admission 1 to test 1 (d) & & & & $<0.001^{2}$ \\
\hline Median & 0.4 & 0.2 & 0.3 & \\
\hline Mean (sd) & $3.0(11.4)$ & $0.7(2.6)$ & $1.6(7.4)$ & \\
\hline Q1, Q3 & $0.2,1.1$ & $0.1,0.6$ & $0.2,0.9$ & \\
\hline Range & $-13.9-133.1$ & $0.0-55.4$ & $-13.9-133.1$ & \\
\hline $\mathrm{N}$ & 555 & 924 & 1479 & \\
\hline Admission 2 to test 1 (d) & & & & $0.999^{2}$ \\
\hline Median & -7.9 & -8.5 & -8.3 & \\
\hline Mean (sd) & $-9.4(9.3)$ & $-9.4(7.5)$ & $-9.4(8.1)$ & \\
\hline Q1, Q3 & $-16.9,-0.9$ & $-14.3,-2.1$ & $-15.4,-1.5$ & \\
\hline Range & $-29.0-1.2$ & $-25.9-0.3$ & $-29.0-1.2$ & \\
\hline $\mathrm{N}$ & 34 & 70 & 104 & \\
\hline Primary Outcome & & & & $<0.001^{1}$ \\
\hline Deceased/Discharged to Hospice & $29(5.0 \%)$ & $72(7.2 \%)$ & $101(6.4 \%)$ & \\
\hline Discharged (not death) & $542(92.8 \%)$ & $865(86.9 \%)$ & $1407(89.1 \%)$ & \\
\hline Intubated (still admitted) & $1(0.2 \%)$ & $44(4.4 \%)$ & $45(2.8 \%)$ & \\
\hline Still admitted (not intubated) & $12(2.1 \%)$ & $14(1.4 \%)$ & $26(1.6 \%)$ & \\
\hline $\mathrm{N}$ & 584 & 995 & 1579 & \\
\hline Deceased & & & & $0.048^{1}$ \\
\hline No & $562(96.2 \%)$ & $933(93.8 \%)$ & $1495(94.7 \%)$ & \\
\hline Yes & $22(3.8 \%)$ & $62(6.2 \%)$ & $84(5.3 \%)$ & \\
\hline $\mathrm{N}$ & 584 & 995 & 1579 & \\
\hline Symptomatic & & & & 0.0041 \\
\hline No & $2(6.9 \%)$ & $10(1.8 \%)$ & $12(2.0 \%)$ & \\
\hline Unknown & $6(20.7 \%)$ & $36(6.4 \%)$ & $42(7.1 \%)$ & \\
\hline Yes & $21(72.4 \%)$ & $514(91.8 \%)$ & $535(90.8 \%)$ & \\
\hline $\mathrm{N}$ & 29 & 560 & 589 & \\
\hline Symptoms start to death (d) & & & & $0.828^{2}$ \\
\hline Median & 11.6 & 14.0 & 13.7 & \\
\hline Mean (sd) & 11.6 (NA) & $14.8(9.3)$ & $14.7(9.2)$ & \\
\hline Q1, Q3 & $11.6,11.6$ & $6.9,19.2$ & $7.0,19.1$ & \\
\hline Range & $11.6-11.6$ & $1.6-39.6$ & $1.6-39.6$ & \\
\hline $\mathrm{N}$ & 1 & 46 & 47 & \\
\hline
\end{tabular}


medRxiv preprint doi: https://doi.org/10.1101/2020.05.06.20093575; this version posted May 8, 2020. The copyright holder for this preprint (which was not certified by peer review) is the author/funder, who has granted medRxiv a license to display the preprint in perpetuity. All rights reserved. No reuse allowed without permission.

\begin{tabular}{|c|c|c|c|c|}
\hline & $\begin{array}{r}\text { Negative } \\
(\mathrm{N}=11352)\end{array}$ & Positive (N=10920) & Total $(\mathrm{N}=22272)$ & $\mathrm{p}$ value \\
\hline Any fever & & & & $0.936^{1}$ \\
\hline No & $5(23.8 \%)$ & $133(25.4 \%)$ & $138(25.4 \%)$ & \\
\hline Yes & $16(76.2 \%)$ & $390(74.6 \%)$ & $406(74.6 \%)$ & \\
\hline $\mathrm{N}$ & 21 & 523 & 544 & \\
\hline Intubated & & & & $0.026^{1}$ \\
\hline No & $543(93.0 \%)$ & $889(89.3 \%)$ & $1432(90.7 \%)$ & \\
\hline Yes & $41(7.0 \%)$ & $106(10.7 \%)$ & $147(9.3 \%)$ & \\
\hline $\mathrm{N}$ & 584 & 995 & 1579 & \\
\hline Extubated & & & & $0.046^{1}$ \\
\hline No & $557(95.4 \%)$ & $969(97.4 \%)$ & $1526(96.6 \%)$ & \\
\hline Yes & $27(4.6 \%)$ & $26(2.6 \%)$ & $53(3.4 \%)$ & \\
\hline $\mathrm{N}$ & 584 & 995 & 1579 & \\
\hline $\begin{array}{l}\text { Symptoms start to intubation } \\
\text { (d) }\end{array}$ & & & & $0.152^{2}$ \\
\hline Median & 7.0 & 8.0 & 8.0 & \\
\hline Mean (sd) & $16.3(19.7)$ & $9.2(7.3)$ & $9.4(7.9)$ & \\
\hline Q1, Q3 & $5.0,23.0$ & $4.2,11.0$ & $4.0,11.0$ & \\
\hline Range & $3.0-39.0$ & $-3.0-39.0$ & $-3.0-39.0$ & \\
\hline $\mathrm{N}$ & 3 & 90 & 93 & \\
\hline Intubation duration (d) & & & & $0.069^{2}$ \\
\hline Median & 3.0 & 6.0 & 5.0 & \\
\hline Mean (sd) & $4.2(4.7)$ & $6.9(4.7)$ & $5.4(4.9)$ & \\
\hline Q1, Q3 & $1.2,5.0$ & $4.5,9.5$ & $2.0,8.0$ & \\
\hline Range & $-3.0-20.0$ & $0.0-20.0$ & $-3.0-20.0$ & \\
\hline $\mathrm{N}$ & 26 & 23 & 49 & \\
\hline Decompensated & & & & $0.005^{1}$ \\
\hline No & $535(91.6 \%)$ & $862(86.6 \%)$ & 1397 (88.5\%) & \\
\hline Yes & $49(8.4 \%)$ & $133(13.4 \%)$ & $182(11.5 \%)$ & \\
\hline $\mathrm{N}$ & 584 & 995 & 1579 & \\
\hline \multicolumn{5}{|c|}{ Symptoms start to decompensation (d) } \\
\hline Median & 9.0 & 8.0 & 8.0 & \\
\hline Mean (sd) & $15.0(16.3)$ & $9.9(8.2)$ & $10.1(8.5)$ & \\
\hline Q1, Q3 & $6.0,18.0$ & $4.0,13.0$ & $4.0,13.0$ & \\
\hline Range & $3.0-39.0$ & $-3.0-39.0$ & $-3.0-39.0$ & \\
\hline $\mathrm{N}$ & 4 & 108 & 112 & \\
\hline \multicolumn{5}{|l|}{ Symptoms start to first test (d) } \\
\hline Median & 4.4 & 4.7 & 4.7 & \\
\hline Mean (sd) & $6.9(13.7)$ & $6.9(17.0)$ & $6.9(16.9)$ & \\
\hline Q1, Q3 & $2.5,12.5$ & $2.7,7.9$ & $2.7,7.9$ & \\
\hline
\end{tabular}


medRxiv preprint doi: https://doi.org/10.1101/2020.05.06.20093575; this version posted May 8, 2020. The copyright holder for this preprint (which was not certified by peer review) is the author/funder, who has granted medRxiv a license to display the preprint in perpetuity.

All rights reserved. No reuse allowed without permission.

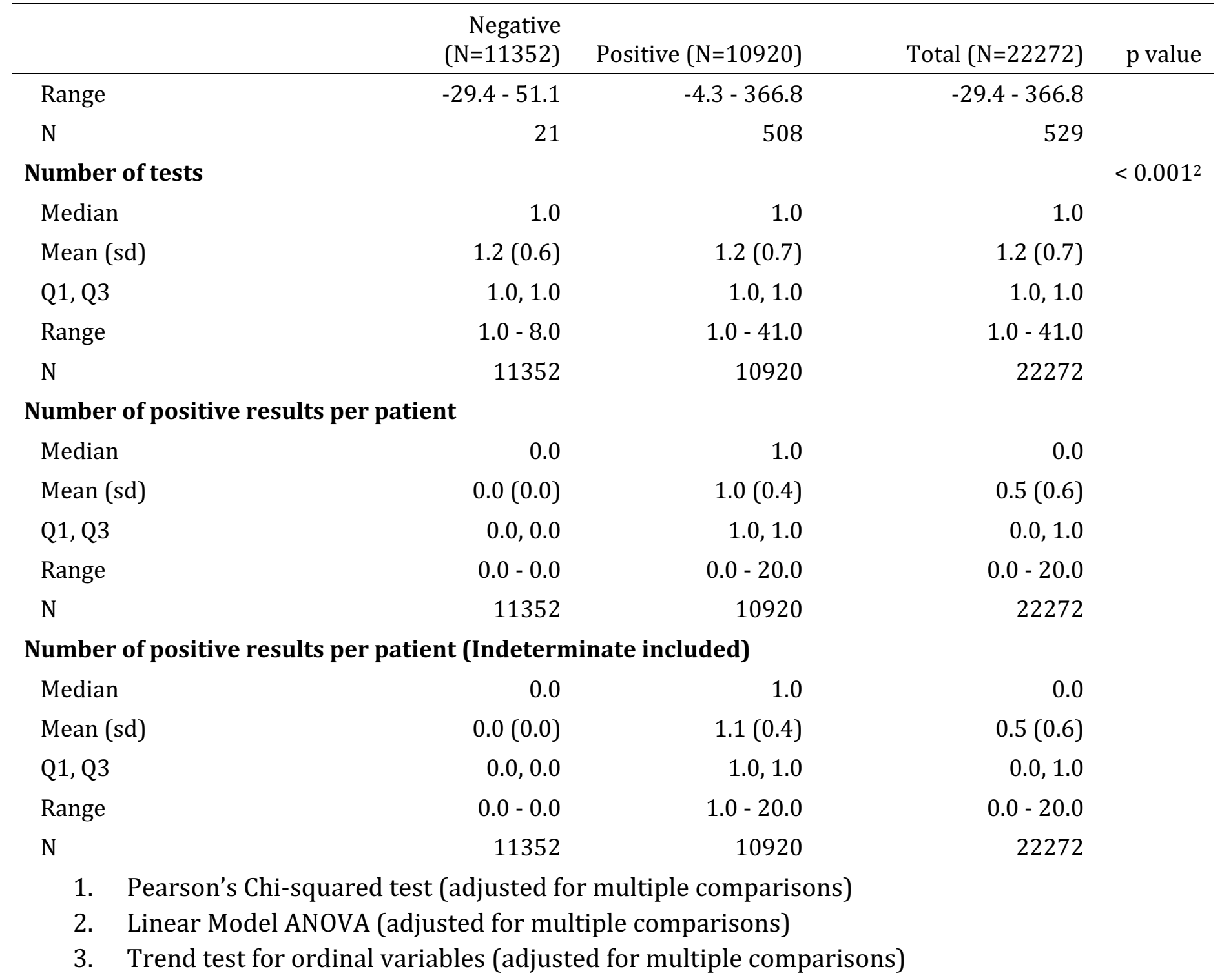


medRxiv preprint doi: https://doi.org/10.1101/2020.05.06.20093575; this version posted May 8, 2020. The copyright holder for this preprint (which was not certified by peer review) is the author/funder, who has granted medRxiv a license to display the preprint in perpetuity. All rights reserved. No reuse allowed without permission.

Supplementary Table 3: Patient characteristics comparing repeat-tested with single-tested patients.

\begin{tabular}{|c|c|c|c|c|}
\hline & Repeat $(N=3432)$ & Single $(N=18906)$ & Total $(\mathrm{N}=22338)$ & $\mathrm{p}$ value \\
\hline Gender at birth & & & & $<0.001^{1}$ \\
\hline Female & $1644(47.9 \%)$ & $10503(55.6 \%)$ & $12147(54.4 \%)$ & \\
\hline Male & $1787(52.1 \%)$ & $8380(44.3 \%)$ & 10167 (45.5\%) & \\
\hline Unknown & $1(0.0 \%)$ & $22(0.1 \%)$ & $23(0.1 \%)$ & \\
\hline $\mathrm{N}$ & 3432 & 18905 & 22337 & \\
\hline Age at order & & & & $<0.001^{2}$ \\
\hline Median & 59.7 & 53.4 & 54.4 & \\
\hline Mean (sd) & $55.5(23.3)$ & $52.7(22.1)$ & $53.1(22.3)$ & \\
\hline Q1, Q3 & $39.6,72.3$ & $35.0,70.0$ & $35.5,70.4$ & \\
\hline Range & $0.0-120.3$ & $0.0-144.7$ & $0.0-144.7$ & \\
\hline $\mathrm{N}$ & 3432 & 18906 & 22338 & \\
\hline Age group (y) & & & & $<0.001^{3}$ \\
\hline $0-19$ & $278(8.1 \%)$ & $949(5.0 \%)$ & $1227(5.5 \%)$ & \\
\hline $20-44$ & $751(21.9 \%)$ & $6569(34.8 \%)$ & $7320(32.8 \%)$ & \\
\hline $45-54$ & $413(12.0 \%)$ & $2384(12.6 \%)$ & 2797 (12.5\%) & \\
\hline $55-64$ & $604(17.6 \%)$ & $2943(15.6 \%)$ & 3547 (15.9\%) & \\
\hline $65-74$ & $673(19.6 \%)$ & $2639(14.0 \%)$ & $3312(14.8 \%)$ & \\
\hline $75-84$ & $450(13.1 \%)$ & $2017(10.7 \%)$ & 2467 (11.0\%) & \\
\hline$>=85$ & $259(7.6 \%)$ & $1402(7.4 \%)$ & $1661(7.4 \%)$ & \\
\hline $\mathrm{N}$ & 3428 & 18903 & 22331 & \\
\hline Ethnicity & & & & $0.231^{1}$ \\
\hline Hispanic/Latino & $92(33.5 \%)$ & $371(28.3 \%)$ & $463(29.2 \%)$ & \\
\hline Not Hispanic/Latino & $121(44.0 \%)$ & $602(46.0 \%)$ & $723(45.6 \%)$ & \\
\hline Not Specified & $62(22.5 \%)$ & $337(25.7 \%)$ & $399(25.2 \%)$ & \\
\hline $\mathrm{N}$ & 275 & 1310 & 1585 & \\
\hline Race & & & & $<0.001^{1}$ \\
\hline Asian & $220(6.4 \%)$ & $1065(5.6 \%)$ & $1285(5.8 \%)$ & \\
\hline $\begin{array}{l}\text { Black or African } \\
\text { American }\end{array}$ & $620(18.1 \%)$ & $2856(15.1 \%)$ & $3476(15.6 \%)$ & \\
\hline Caucasian & $963(28.1 \%)$ & $5006(26.5 \%)$ & $5969(26.7 \%)$ & \\
\hline Declined & $476(13.9 \%)$ & $2432(12.9 \%)$ & 2908 (13.0\%) & \\
\hline Other & $633(18.4 \%)$ & $3431(18.1 \%)$ & $4064(18.2 \%)$ & \\
\hline Pacific Islander & $12(0.3 \%)$ & $34(0.2 \%)$ & $46(0.2 \%)$ & \\
\hline Unavailable & $508(14.8 \%)$ & $4082(21.6 \%)$ & $4590(20.5 \%)$ & \\
\hline $\mathrm{N}$ & 3432 & 18906 & 22338 & \\
\hline Highest level of care & & & & $<0.001^{1}$ \\
\hline Admitted & $120(45.1 \%)$ & $414(35.6 \%)$ & $534(37.4 \%)$ & \\
\hline Discharged from ED & $16(6.0 \%)$ & $113(9.7 \%)$ & $129(9.0 \%)$ & \\
\hline
\end{tabular}


medRxiv preprint doi: https://doi.org/10.1101/2020.05.06.20093575; this version posted May 8, 2020. The copyright holder for this preprint (which was not certified by peer review) is the author/funder, who has granted medRxiv a license to display the preprint in perpetuity. All rights reserved. No reuse allowed without permission.
ICU-level Care
Outpatient
$\mathrm{N}$
Encounter type at order

$$
\begin{array}{r}
79(29.7 \%) \\
51(19.2 \%) \\
266
\end{array}
$$

$$
\begin{aligned}
& \text { Emergency } \\
& \text { Inpatient } \\
& \text { Outpatient } \\
& \mathrm{N}
\end{aligned}
$$

\section{Location at order}

Allen Hospital

Columbia

Columbia Outreach

Lower Manhattan

NYHQ

Weill Cornell

WESTCHESTER

$\mathrm{N}$

\section{Number of admissions}

Median

Mean (sd)

Q1, Q3

Range

$\mathrm{N}$

\section{Admission duration (d)}

Median

Mean (sd)

Q1, Q3

Range

$\mathrm{N}$

Admission 1 to test 1 (d)

Median

Mean (sd)

Q1, Q3

Range

$$
\mathrm{N}
$$

Admission 2 to test 1 (d)

Median

$-9.0$

$-10.6(7.8)$

$-15.8,-4.0$

$-29.0-0.5$

$$
\begin{array}{r}
204(5.9 \%) \\
1434(41.8 \%) \\
116(3.4 \%) \\
161(4.7 \%) \\
495(14.4 \%) \\
973(28.4 \%) \\
49(1.4 \%) \\
3432
\end{array}
$$

$0.9(0.6)$

$0.0,1.0$

$0.0-2.0$

275

5.8

$11.6(13.5)$

$1.0,19.4$

$0.0-83.5$

275

0.4

$2.3(6.7)$

$0.2,1.1$

$-13.9-56.1$

268

Mean (sd)

Q1, Q3

Range

$$
\begin{array}{rr}
109(9.4 \%) & 188(13.2 \%) \\
526(45.3 \%) & 577(40.4 \%) \\
1162 & 1428
\end{array}
$$

$$
\begin{array}{r}
1273(37.1 \%) \\
1400(40.8 \%) \\
759(22.1 \%) \\
3432
\end{array}
$$

$$
\begin{array}{r}
6197(32.8 \%) \\
4998(26.4 \%) \\
7711(40.8 \%) \\
18906
\end{array}
$$

$$
\begin{array}{r}
1099(5.8 \%) \\
7031(37.2 \%) \\
1144(6.1 \%) \\
911(4.8 \%) \\
3654(19.3 \%) \\
4936(26.1 \%) \\
131(0.7 \%) \\
18906
\end{array}
$$

0.0

$0.4(0.5)$

$0.0,1.0$

$0.0-1.0$

1312

0.6

3.5 (9.3)

$0.3,2.9$

0.0 - 139.0

1312

0.3

$1.4(7.5)$

$0.2,0.9$

0.0 - 133.1

1218

0.1

$-2.6(5.9)$

$-1.2,0.2$

$-19.1-1.2$
$<0.001^{1}$

7470 (33.4\%)

$6398(28.6 \%)$

8470 (37.9\%)

22338

$<0.001^{1}$

1303 (5.8\%)

8465 (37.9\%)

$1260(5.6 \%)$

1072 (4.8\%)

4149 (18.6\%)

5909 (26.5\%)

$180(0.8 \%)$

22338

$<0.001^{2}$

0.0

$0.5(0.5)$

$0.0,1.0$

$0.0-2.0$

1587

$<0.001^{2}$

0.7

4.9 (10.6)

$0.3,4.4$

0.0 - 139.0

1587

$0.112^{2}$

0.3

1.6 (7.3)

$0.2,0.9$

-13.9 - 133.1

1486

$<0.001^{2}$

$-8.3$

$-9.4(8.1)$

$-15.4,-1.5$

$-29.0-1.2$ 
medRxiv preprint doi: https://doi.org/10.1101/2020.05.06.20093575; this version posted May 8, 2020. The copyright holder for this preprint (which was not certified by peer review) is the author/funder, who has granted medRxiv a license to display the preprint in perpetuity. All rights reserved. No reuse allowed without permission.

$\mathrm{N}$

Primary Outcome

Deceased/Discharged to

Hospice

Discharged (not death)

Intubated (still admitted)

Still admitted (not intubated)

$\mathrm{N}$

\section{Deceased}

No

Yes

$\mathrm{N}$

\section{Symptomatic}

No

Unknown

Yes

$\mathrm{N}$

\section{Symptoms start to death (d)}

Median

Mean (sd)

Q1, Q3

Range

$\mathrm{N}$

\section{Any fever}

No

Yes

$\mathrm{N}$

Intubated

No

Yes

$\mathrm{N}$

\section{Extubated}

No

Yes

$\mathrm{N}$

\section{Symptoms start to intubation (d)}

Median

9.0

$10.9(7.0)$

$7.0,14.0$

$0.0-30.0$

Mean (sd)

Q1, Q3

Range
16

104

$$
\begin{array}{r}
27(9.8 \%) \\
196(71.3 \%) \\
31(11.3 \%) \\
21(7.6 \%)
\end{array}
$$

275

$$
\begin{array}{r}
253(92.0 \%) \\
22(8.0 \%) \\
275
\end{array}
$$

4 (3.8\%)

$2(1.9 \%)$

99 (94.3\%)

105

12.3

17.4 (11.9)

$9.8,25.6$

$3.3-39.6$

10

$$
\begin{aligned}
& 25(25.0 \%) \\
& 75(75.0 \%)
\end{aligned}
$$

100

$$
\begin{array}{r}
208(75.6 \%) \\
67(24.4 \%) \\
275
\end{array}
$$

251 (91.3\%)

24 (8.7\%)

275

$8(1.6 \%)$

42 (8.6\%)

436 (89.7\%)

486

14.3

14.0 (8.4)

$6.9,19.1$

$1.6-38.3$

37

113 (25.5\%)

331 (74.5\%)

444

1232 (93.9\%)

80 (6.1\%)

1312

1283 (97.8\%)

$29(2.2 \%)$

1312
$<0.001^{1}$

$101(6.4 \%)$

1415 (89.2\%)

45 (2.8\%)

26 (1.6\%)

1587

$0.038^{1}$

1503 (94.7\%)

84 (5.3\%)

1587

$0.035^{1}$

12 (2.0\%)

44 (7.4\%)

535 (90.5\%)

591

$0.320^{2}$

13.7

14.7 (9.2)

7.0, 19.1

$1.6-39.6$

47

$0.925^{1}$

138 (25.4\%)

406 (74.6\%)

544

$<0.001^{1}$

$1440(90.7 \%)$

147 (9.3\%)

1587

$<0.001^{1}$

1534 (96.7\%)

53 (3.3\%)

1587

7.0

8.0

8.3 (8.4)

9.4 (7.9)

$3.0,10.2$

$4.0,11.0$

$-3.0-39.0$

$-3.0-39.0$ 
medRxiv preprint doi: https://doi.org/10.1101/2020.05.06.20093575; this version posted May 8, 2020. The copyright holder for this preprint (which was not certified by peer review) is the author/funder, who has granted medRxiv a license to display the preprint in perpetuity. All rights reserved. No reuse allowed without permission.

$\mathrm{N}$

Intubation duration (d)

Median

Mean (sd)

Q1, Q3

Range

$\mathrm{N}$

Decompensated

No

Yes

$\mathrm{N}$
41

5.0

$6.3(5.5)$

2.5, 8.5

$1.0-20.0$

23

$199(72.4 \%)$

$76(27.6 \%)$

275

Symptoms start to decompensation (d)

Median

Mean (sd)

11.7 (8.3)

Q1, Q3

7.0, 15.0

Range

$0.0-39.0$

N

Symptoms start to first test (d)

Median

Mean (sd)

$9.8(36.8)$

Q1, Q3

$2.1,8.3$

Range

$-4.3-366.8$

$\mathrm{N}$

98

\section{Number of tests}

Median

2.5 (1.1)

$2.0,3.0$

Q1, Q3

$1.0-41.0$

3432

45

$\mathrm{N}$
52

4.5

4.7 (4.2)

$1.0,7.8$

$-3.0-13.0$

26

1206 (91.9\%)

$106(8.1 \%)$

1312

93

$0.297^{2}$

5.0

5.4 (4.9)

2.0, 8.0

$-3.0-20.0$

49

$<0.001^{1}$

1405 (88.5\%)

182 (11.5\%)

1587

7.0

8.0

9.0 (8.6)

10.1 (8.5)

$3.5,11.0$

4.0, 13.0

$-3.0-39.0$

$-3.0-39.0$

67

112

4.6

4.7

6.3 (6.4)

6.9 (16.9)

2.8, 7.8

$2.7,7.9$

$-29.4-60.8$

$-29.4-366.8$

431

529

$<0.001^{2}$

1.0

1.0

$1.0(0.0)$

$1.2(0.7)$

1.0, 1.0

$1.0,1.0$

$1.0-1.0$

$1.0-41.0$

18906

22338

0.0

0.0

0.0

Median

$0.6(0.9)$

$0.5(0.5)$

$0.5(0.6)$

Q1, Q3

$0.0,1.0$

$0.0,1.0$

$0.0,1.0$

Range

$0.0-20.0$

$0.0-1.0$

$0.0-20.0$

3432

18906

22338

Number of positive results per patient (indeterminate included)

Median

0.0

0.0

0.0

Mean (sd)

$0.7(1.0)$

$0.5(0.5)$

$0.5(0.6)$

Q1, Q3

$0.0,1.0$

$0.0,1.0$

$0.0,1.0$

Range

$0.0-20.0$

$0.0-1.0$

$0.0-20.0$ 
medRxiv preprint doi: https://doi.org/10.1101/2020.05.06.20093575; this version posted May 8, 2020. The copyright holder for this preprint (which was not certified by peer review) is the author/funder, who has granted medRxiv a license to display the preprint in perpetuity.

$\mathrm{N}$

3432

18906

22338

1.

Highest SARS-CoV-2 Result

Invalid

$1(0.0 \%)$

$65(0.3 \%)$

$66(0.3 \%)$

Not Detected

1960 (57.1\%)

$9392(49.7 \%)$

11352 (50.8\%)

Indeterminate

$100(2.9 \%)$

177 (0.9\%)

277 (1.2\%)

Detected

$1371(39.9 \%)$

$9272(49.0 \%)$

$10643(47.6 \%)$

$\mathrm{N}$

3432

18906

22338

Pearson's Chi-squared test (adjusted for multiple comparisons)

2. Linear Model ANOVA (adjusted for multiple comparisons)

3. Trend test for ordinal variables (adjusted for multiple comparisons) 
medRxiv preprint doi: https://doi.org/10.1101/2020.05.06.20093575; this version posted May 8, 2020. The copyright holder for this preprint (which was not certified by peer review) is the author/funder, who has granted medRxiv a license to display the preprint in perpetuity. All rights reserved. No reuse allowed without permission.

Supplementary Table 4: SARS-CoV-2 molecular tests in repeat-tested vs. single-tested patients. N represents the number of tests in each category.

\begin{tabular}{|c|c|c|c|c|}
\hline & Repeat $(\mathrm{N}=8471)$ & Single $(N=18906)$ & Total $(\mathrm{N}=27377)$ & $\mathrm{p}$ value \\
\hline Method & & & & $<0.001^{1}$ \\
\hline cobas 6800 & $5841(69.0 \%)$ & $13354(70.6 \%)$ & 19195 (70.1\%) & \\
\hline Infiniti & $1900(22.4 \%)$ & $4054(21.4 \%)$ & $5954(21.7 \%)$ & \\
\hline GeneXpert & $91(1.1 \%)$ & $174(0.9 \%)$ & $265(1.0 \%)$ & \\
\hline ID Now & $9(0.1 \%)$ & $44(0.2 \%)$ & $53(0.2 \%)$ & \\
\hline Panther Fusion & $11(0.1 \%)$ & $15(0.1 \%)$ & $26(0.1 \%)$ & \\
\hline QuantStudio & $571(6.7 \%)$ & $1224(6.5 \%)$ & 1795 (6.6\%) & \\
\hline 7500 Fast & $48(0.6 \%)$ & $41(0.2 \%)$ & $89(0.3 \%)$ & \\
\hline $\mathrm{N}$ & 8471 & 18906 & 27377 & \\
\hline cobas & & & & $<0.001^{2}$ \\
\hline No & $8471(100.0 \%)$ & $18906(100.0 \%)$ & 27377 (100.0\%) & \\
\hline $\mathrm{N}$ & 8471 & 18906 & 27377 & \\
\hline Initial result & & & & $<0.001^{1}$ \\
\hline Invalid & $554(6.5 \%)$ & $65(0.3 \%)$ & $619(2.3 \%)$ & \\
\hline Not Detected & $5613(66.3 \%)$ & 9392 (49.7\%) & 15005 (54.8\%) & \\
\hline Indeterminate & $265(3.1 \%)$ & 177 (0.9\%) & $442(1.6 \%)$ & \\
\hline Detected & $2039(24.1 \%)$ & $9272(49.0 \%)$ & $11311(41.3 \%)$ & \\
\hline $\mathrm{N}$ & 8471 & 18906 & 27377 & \\
\hline Highest result on day 1 & & & & $<0.001^{1}$ \\
\hline Invalid & 367 (4.3\%) & $65(0.3 \%)$ & $432(1.6 \%)$ & \\
\hline Not Detected & $5501(64.9 \%)$ & $9392(49.7 \%)$ & $14893(54.4 \%)$ & \\
\hline Indeterminate & $267(3.2 \%)$ & $177(0.9 \%)$ & $444(1.6 \%)$ & \\
\hline Detected & $2336(27.6 \%)$ & $9272(49.0 \%)$ & 11608 (42.4\%) & \\
\hline $\mathrm{N}$ & 8471 & 18906 & 27377 & \\
\hline Highest result any day & & & & $<0.001^{1}$ \\
\hline Invalid & $2(0.0 \%)$ & $65(0.3 \%)$ & $67(0.2 \%)$ & \\
\hline Not Detected & $4775(56.4 \%)$ & $9392(49.7 \%)$ & 14167 (51.7\%) & \\
\hline Indeterminate & $246(2.9 \%)$ & $177(0.9 \%)$ & $423(1.5 \%)$ & \\
\hline Detected & $3448(40.7 \%)$ & $9272(49.0 \%)$ & $12720(46.5 \%)$ & \\
\hline $\mathrm{N}$ & 8471 & 18906 & 27377 & \\
\hline Control Ct & & & & $<0.001^{3}$ \\
\hline Median & 34.0 & 33.9 & 33.9 & \\
\hline Mean (sd) & $34.2(1.1)$ & $34.1(1.0)$ & $34.1(1.0)$ & \\
\hline Q1, Q3 & $33.5,34.7$ & $33.4,34.5$ & $33.5,34.6$ & \\
\hline Range & $32.5-41.2$ & $32.4-40.5$ & $32.4-41.2$ & \\
\hline $\mathrm{N}$ & 2144 & 7262 & 9406 & \\
\hline Target $1 \mathbf{C t}$ & & & & $0.036^{3}$ \\
\hline
\end{tabular}


medRxiv preprint doi: https://doi.org/10.1101/2020.05.06.20093575; this version posted May 8, 2020. The copyright holder for this preprint (which was not certified by peer review) is the author/funder, who has granted medRxiv a license to display the preprint in perpetuity. All rights reserved. No reuse allowed without permission.

\begin{tabular}{|c|c|c|c|c|}
\hline & Repeat $(\mathrm{N}=8471)$ & Single $(N=18906)$ & Total $(\mathrm{N}=27377)$ & $\mathrm{p}$ value \\
\hline Median & 27.5 & 26.6 & 26.7 & \\
\hline Mean (sd) & $26.7(5.5)$ & $26.2(5.5)$ & $26.3(5.5)$ & \\
\hline Q1, Q3 & $22.3,31.4$ & $21.8,31.0$ & $21.9,31.0$ & \\
\hline Range & $13.3-36.8$ & $12.4-38.0$ & $12.4-38.0$ & \\
\hline $\mathrm{N}$ & 744 & 4533 & 5277 & \\
\hline Target $2 \mathrm{Ct}$ & & & & $<0.001^{3}$ \\
\hline Median & 29.1 & 27.3 & 27.6 & \\
\hline Mean (sd) & $28.5(6.5)$ & $27.3(6.1)$ & $27.5(6.2)$ & \\
\hline Q1, Q3 & $23.2,34.0$ & $22.3,32.5$ & $22.5,32.7$ & \\
\hline Range & $13.7-39.8$ & $12.9-43.7$ & $12.9-43.7$ & \\
\hline $\mathrm{N}$ & 795 & 4548 & 5343 & \\
\hline Target $2 \mathrm{Ct}>30$ & & & & $<0.001^{1}$ \\
\hline FALSE & $431(54.2 \%)$ & $2869(63.1 \%)$ & $3300(61.8 \%)$ & \\
\hline TRUE & 364 (45.8\%) & 1679 (36.9\%) & $2043(38.2 \%)$ & \\
\hline $\mathrm{N}$ & 795 & 4548 & 5343 & \\
\hline $\begin{array}{l}\text { 1. Pearson' } \\
\text { 2. Chi-squa } \\
\text { 3. Linear M }\end{array}$ & $\begin{array}{l}\text { squared test (adjus } \\
\text { st for given probal } \\
\text { NOVA (adjusted fo }\end{array}$ & $\begin{array}{l}\text { ted for multiple cc } \\
\text { ilities (adjusted fo } \\
\text { r multiple compar }\end{array}$ & $\begin{array}{l}\text { mparisons) } \\
\text { r multiple compar } \\
\text { isons) }\end{array}$ & risons) \\
\hline
\end{tabular}


medRxiv preprint doi: https://doi.org/10.1101/2020.05.06.20093575; this version posted May 8, 2020. The copyright holder for this preprint (which was not certified by peer review) is the author/funder, who has granted medRxiv a license to display the preprint in perpetuity.

All rights reserved. No reuse allowed without permission.

Supplementary Table 5: Number of SARS-CoV-2 molecular test results of repeat-tested patients on day 1 of testing. Rows represent the initial test result and columns the highest test result on day 1.

\begin{tabular}{rrrrrr}
\hline $\begin{array}{r}\text { Highest First Day } \\
\text { Result } \rightarrow\end{array}$ & $\begin{array}{r}\text { Invalid } \\
(\mathrm{N}=163)\end{array}$ & $\begin{array}{r}\text { Not Detected } \\
(\mathrm{N}=2250)\end{array}$ & $\begin{array}{r}\text { Indeterminate } \\
(\mathrm{N}=112)\end{array}$ & $\begin{array}{r}\text { Detected } \\
(\mathrm{N}=907)\end{array}$ & $\begin{array}{r}\text { Total } \\
(\mathrm{N}=3432)\end{array}$ \\
\hline Initial Result & & & & & $\mathrm{p}$ value $<0.0011$ \\
Invalid & $163(100 \%)$ & $32(1.4 \%)$ & $1(0.9 \%)$ & $45(5.0 \%)$ & $241(7.0 \%)$ \\
Not Detected & $0(0.0 \%)$ & $2218(98.6 \%)$ & $13(11.6 \%)$ & $49(5.4 \%)$ & $2280(66.4 \%)$ \\
Indeterminate & $0(0.0 \%)$ & $0(0.0 \%)$ & $98(87.5 \%)$ & $16(1.8 \%)$ & $114(3.3 \%)$ \\
Detected & $0(0.0 \%)$ & $0(0.0 \%)$ & $0(0.0 \%)$ & $797(87.9 \%)$ & $797(23.2 \%)$
\end{tabular}

1. Pearson's Chi-squared test (adjusted for multiple comparisons)

Supplementary Table 6: Number of SARS-CoV-2 molecular test results over the course of repeat testing, grouped by the initial test result on day 1.

\begin{tabular}{rrrrrr}
\hline $\begin{array}{r}\text { Highest Result } \\
\text { Any Day } \rightarrow\end{array}$ & $\begin{array}{r}\text { Invalid } \\
(\mathrm{N}=1)\end{array}$ & $\begin{array}{r}\text { Not Detected } \\
(\mathrm{N}=1960)\end{array}$ & $\begin{array}{r}\text { Indeterminate } \\
(\mathrm{N}=100)\end{array}$ & $\begin{array}{r}\text { Detected } \\
(\mathrm{N}=1371)\end{array}$ & $\begin{array}{r}\text { Total }(\mathrm{N}=3432) \\
\text { Initial Result }\end{array}$ \\
Invalid & $1(100 \%)$ & $110(5.6 \%)$ & $3(3.0 \%)$ & $127(9.3 \%)$ & $241(7.0 \%)$ \\
Not Detected & $0(0.0 \%)$ & $1850(94.4 \%)$ & $45(45.0 \%)$ & $385(28.1 \%)$ & $2280(66.4 \%)$ \\
Indeterminate & $0(0.0 \%)$ & $0(0.0 \%)$ & $52(52.0 \%)$ & $62(4.5 \%)$ & $114(3.3 \%)$ \\
Detected & $0(0.0 \%)$ & $0(0.0 \%)$ & $0(0.0 \%)$ & $797(58.1 \%)$ & $797(23.2 \%)$
\end{tabular}

1. Pearson's Chi-squared test (adjusted for multiple comparisons) 
Supplementary Table 7: Characteristics of initially positive repeat-tested patients comparing those that converted from positive to negative (Pos2neg) with those that remained positive (Unchanged pos).

\begin{tabular}{|c|c|c|c|c|}
\hline & $\begin{array}{l}\text { Pos2neg } \\
(\mathrm{N}=330)\end{array}$ & $\begin{array}{r}\text { Unchanged pos } \\
(\mathrm{N}=413)\end{array}$ & $\begin{array}{r}\text { Total } \\
(\mathrm{N}=743)\end{array}$ & $\mathrm{p}$ value \\
\hline Gender at birth & & & & 0.5991 \\
\hline Female & $138(41.8 \%)$ & $162(39.2 \%)$ & $300(40.4 \%)$ & \\
\hline Male & $192(58.2 \%)$ & $251(60.8 \%)$ & $443(59.6 \%)$ & \\
\hline $\mathrm{N}$ & 330 & 413 & 743 & \\
\hline Age at order & & & & $0.014^{2}$ \\
\hline Median & 58.6 & 62.6 & 61.3 & \\
\hline Mean (sd) & $56.4(18.2)$ & $60.3(18.3)$ & $58.6(18.4)$ & \\
\hline Q1, Q3 & $46.2,68.2$ & $49.7,73.1$ & $48.2,70.9$ & \\
\hline Range & $0.0-100.4$ & $0.0-96.5$ & $0.0-100.4$ & \\
\hline $\mathrm{N}$ & 330 & 413 & 743 & \\
\hline Age group (y) & & & & $0.014^{3}$ \\
\hline $0-19$ & $11(3.3 \%)$ & $11(2.7 \%)$ & $22(3.0 \%)$ & \\
\hline $20-44$ & $64(19.4 \%)$ & $71(17.2 \%)$ & $135(18.2 \%)$ & \\
\hline $45-54$ & $62(18.8 \%)$ & $60(14.5 \%)$ & $122(16.4 \%)$ & \\
\hline $55-64$ & $80(24.2 \%)$ & $83(20.1 \%)$ & $163(21.9 \%)$ & \\
\hline $65-74$ & $72(21.8 \%)$ & $102(24.7 \%)$ & $174(23.4 \%)$ & \\
\hline $75-84$ & $30(9.1 \%)$ & $62(15.0 \%)$ & $92(12.4 \%)$ & \\
\hline$>=85$ & $11(3.3 \%)$ & $24(5.8 \%)$ & $35(4.7 \%)$ & \\
\hline $\mathrm{N}$ & 330 & 413 & 743 & \\
\hline Ethnicity & & & & $0.721^{1}$ \\
\hline Hispanic/Latino & $15(30.6 \%)$ & $15(39.5 \%)$ & $30(34.5 \%)$ & \\
\hline Not Hispanic/Latino & $22(44.9 \%)$ & $14(36.8 \%)$ & $36(41.4 \%)$ & \\
\hline Not Specified & $12(24.5 \%)$ & $9(23.7 \%)$ & $21(24.1 \%)$ & \\
\hline $\mathrm{N}$ & 49 & 38 & 87 & \\
\hline Race & & & & 0.3141 \\
\hline Asian & $24(7.3 \%)$ & $19(4.6 \%)$ & $43(5.8 \%)$ & \\
\hline $\begin{array}{l}\text { Black or African } \\
\text { American }\end{array}$ & $57(17.3 \%)$ & $66(16.0 \%)$ & $123(16.6 \%)$ & \\
\hline Caucasian & $81(24.5 \%)$ & $115(27.8 \%)$ & $196(26.4 \%)$ & \\
\hline Declined & $55(16.7 \%)$ & $47(11.4 \%)$ & $102(13.7 \%)$ & \\
\hline Other & $62(18.8 \%)$ & $91(22.0 \%)$ & $153(20.6 \%)$ & \\
\hline Pacific Islander & $3(0.9 \%)$ & $3(0.7 \%)$ & $6(0.8 \%)$ & \\
\hline Unavailable & $48(14.5 \%)$ & $72(17.4 \%)$ & $120(16.2 \%)$ & \\
\hline $\mathrm{N}$ & 330 & 413 & 743 & \\
\hline Highest level of care & & & & $0.241^{1}$ \\
\hline Admitted & $12(27.9 \%)$ & $11(29.7 \%)$ & $23(28.8 \%)$ & \\
\hline Discharged from ED & $5(11.6 \%)$ & $1(2.7 \%)$ & $6(7.5 \%)$ & \\
\hline
\end{tabular}


medRxiv preprint doi: https://doi.org/10.1101/2020.05.06.20093575; this version posted May 8, 2020. The copyright holder for this preprint (which was not certified by peer review) is the author/funder, who has granted medRxiv a license to display the preprint in perpetuity.

All rights reserved. No reuse allowed without permission.

\begin{tabular}{l}
\hline ICU-level Care \\
Outpatient \\
$\mathrm{N}$ \\
Encounter type at order
\end{tabular}

Emergency

Inpatient

Outpatient

$\mathrm{N}$

\section{Location at order}

Allen Hospital

Columbia

Columbia Outreach

Lower Manhattan

Queens

Weill Cornell

Westchester

$\mathrm{N}$

\section{Number of admissions}

Median

Mean (sd)

Q1, Q3

Range

$\mathrm{N}$

Admission duration (d)

Median

Mean (sd)

Q1, Q3

Range

$\mathrm{N}$

Admission 1 to test 1 (d)

Median

Mean (sd)

Q1, Q3

Range

$\mathrm{N}$

Admission 2 to test 1 (d)

\section{Pos2neg Unchanged pos}

$(\mathrm{N}=330)$

22 (51.2\%)

$4(9.3 \%)$

43

$19(5.8 \%)$
$216(65.5 \%)$
$95(28.8 \%)$
330

$9(2.7 \%)$

$162(49.1 \%)$

$0(0.0 \%)$

$7(2.1 \%)$

35 (10.6\%)

$114(34.5 \%)$

3 (0.9\%)

330

1.0

0.7 (0.5)

$0.0,1.0$

$0.0-2.0$

49

22.9

$17.6(16.4)$

$0.4,28.3$

$0.0-82.2$

49

28.1

28.3 (10.4)

$23.1,33.4$

$0.8-69.0$

43

8.6
15 (40.5\%)

$10(27.0 \%)$

37

$56(13.6 \%)$

278 (67.3\%)

79 (19.1\%)

413

$18(4.4 \%)$

165 (40.0\%)

8 (1.9\%)

$11(2.7 \%)$

73 (17.7\%)

136 (32.9\%)

2 (0.5\%)

413

1.0

$0.8(0.7)$

$0.0,1.0$

$0.0-2.0$

38

6.6

$13.1(13.0)$

1.0, 27.7

0.2 - 38.6

38

20.6

20.7 (12.2)

$12.2,31.5$

$0.4-42.6$

38

0.2
Total

$(\mathrm{N}=743)$

$p$ value

37 (46.2\%)

$14(17.5 \%)$

80

$<0.001^{1}$

75 (10.1\%)

494 (66.5\%)

174 (23.4\%)

743

$0.018^{1}$

27 (3.6\%)

327 (44.0\%)

$8(1.1 \%)$

18 (2.4\%)

108 (14.5\%)

250 (33.6\%)

$5(0.7 \%)$

743

$0.629^{2}$

1.0

$0.8(0.6)$

$0.0,1.0$

$0.0-2.0$

87

$0.314^{2}$

12.3

15.7 (15.1)

$0.7,28.2$

$0.0-82.2$

87

$0.014^{2}$

25.7

24.7 (11.9)

$16.3,32.9$

$0.4-69.0$

81

$0.182^{2}$

0.3

6.4 (10.2) 
medRxiv preprint doi: https://doi.org/10.1101/2020.05.06.20093575; this version posted May 8, 2020. The copyright holder for this preprint (which was not certified by peer review) is the author/funder, who has granted medRxiv a license to display the preprint in perpetuity. All rights reserved. No reuse allowed without permission.

\begin{tabular}{l}
\hline Q1, Q3 \\
Range \\
$\mathrm{N}$ \\
Primary Outcome \\
Deceased/Discharged to \\
Hospice \\
Discharged (not death) \\
Intubated (still \\
admitted) \\
Still admitted (not \\
intubated) \\
$\mathrm{N}$
\end{tabular}

\begin{tabular}{rrr}
$\begin{array}{r}\text { Pos2neg } \\
(\mathrm{N}=330)\end{array}$ & Unchanged pos & $\begin{array}{r}\text { Total } \\
(\mathrm{N}=413)\end{array}$ \\
\hline $0.7,21.3$ & $0.2,1.5$ & $0.2,8.3$ \\
$0.2-32.6$ & $0.1-28.3$ & $0.1-32.6$ \\
8 & 16 & 24
\end{tabular}

\section{Deceased}

No

Yes

$\mathrm{N}$

\section{Symptomatic}

No

Unknown

Yes

$\mathrm{N}$

Symptoms start to death (d)

Median

Mean (sd)

Q1, Q3

Range

$\mathrm{N}$

Any fever

No

Yes

$\mathrm{N}$

$24(49.0 \%)$
$17(34.7 \%)$

$7(14.3 \%)$

49

$48(98.0 \%)$
$1(2.0 \%)$
49

$1(2.5 \%)$

$0(0.0 \%)$

$39(97.5 \%)$

40

39.6

39.6 (NA)

39.6, 39.6

39.6 - 39.6

1

$11(28.2 \%)$

$28(71.8 \%)$

39

Intubated

No

Yes

$\mathrm{N}$

\section{Extubated}

No

Yes

$\mathrm{N}$

$$
\begin{array}{r}
44(89.8 \%) \\
5(10.2 \%)
\end{array}
$$

49
Total

$p$ value

$0.241^{1}$

$4(4.6 \%)$

48 (55.2\%)

27 (31.0\%)

$8(9.2 \%)$

87

$0.314^{1}$

$83(95.4 \%)$

4 (4.6\%)

87

$3(4.8 \%)$

$0(0.0 \%)$

60 (95.2\%)

63

$0.327^{2}$

13.7

22.0

$18.2(10.6)$

23.5 (13.8)

$12.1,22.0$

$12.9,32.6$

$10.6-30.3$

10.6 - 39.6

3

0.7441

5 (23.8\%)

$16(26.7 \%)$

16 (76.2\%)

44 (73.3\%)

21

60

$0.327^{1}$

25 (65.8\%)

51 (58.6\%)

13 (34.2\%)

36 (41.4\%)

38

87

$0.128^{1}$

82 (94.3\%)

5 (5.7\%)
38 (100.0\%)

$0(0.0 \%)$

38 


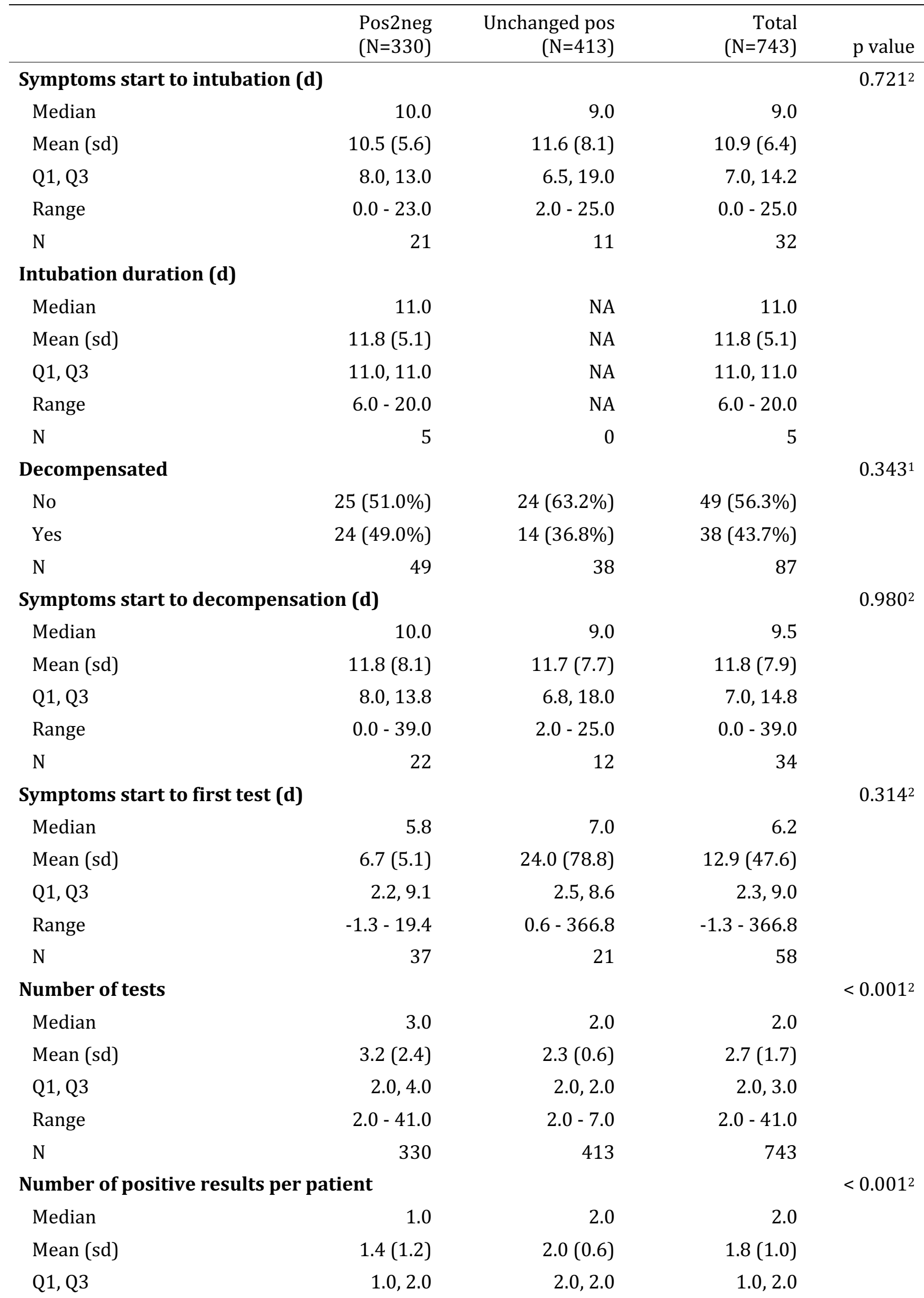


medRxiv preprint doi: https://doi.org/10.1101/2020.05.06.20093575; this version posted May 8, 2020. The copyright holder for this preprint (which was not certified by peer review) is the author/funder, who has granted medRxiv a license to display the preprint in perpetuity. All rights reserved. No reuse allowed without permission.

\begin{tabular}{crrrr}
\hline \multicolumn{1}{c}{} & $\begin{array}{c}\text { Pos2neg } \\
(\mathrm{N}=330)\end{array}$ & $\begin{array}{r}\text { Unchanged pos } \\
(\mathrm{N}=413)\end{array}$ & $\begin{array}{r}\text { Total } \\
(\mathrm{N}=743)\end{array}$ & p value \\
\hline Range & $1.0-20.0$ & $1.0-7.0$ & $1.0-20.0$ & 743 \\
$\mathrm{~N}$ & 330 & 413 & \\
1. & Pearson's Chi-squared test (adjusted for multiple comparisons) \\
2. & Linear Model ANOVA (adjusted for multiple comparisons) \\
3. & Trend test for ordinal variables (adjusted for multiple comparisons)
\end{tabular}


medRxiv preprint doi: https://doi.org/10.1101/2020.05.06.20093575; this version posted May 8, 2020. The copyright holder for this preprint (which was not certified by peer review) is the author/funder, who has granted medRxiv a license to display the preprint in perpetuity. All rights reserved. No reuse allowed without permission.

Supplementary Table 8: Characteristics of repeat-tested initially negative patients comparing those that converted from negative to positive (Neg2pos), with those that remained negative (Unchanged neg) or indeterminate (Unchanged ind) patients.

\begin{tabular}{|c|c|c|c|c|c|c|}
\hline & $\begin{array}{l}\text { Neg2pos } \\
(\mathrm{N}=417)\end{array}$ & $\begin{array}{r}\text { Pos2neg } \\
(\mathrm{N}=4)\end{array}$ & $\begin{array}{l}\text { Unchanged } \\
\text { ind }(\mathrm{N}=43)\end{array}$ & $\begin{array}{l}\text { Unchanged neg } \\
\qquad(\mathrm{N}=1705)\end{array}$ & $\begin{array}{r}\text { Total } \\
(\mathrm{N}=2169)\end{array}$ & $\mathrm{p}$ value \\
\hline Gender at birth & & & & & & $0.062^{1}$ \\
\hline Female & $192(46.0 \%)$ & $1(25.0 \%)$ & $20(46.5 \%)$ & $900(52.8 \%)$ & $1113(51.3 \%)$ & \\
\hline Male & 225 (54.0\%) & $3(75.0 \%)$ & $23(53.5 \%)$ & 805 (47.2\%) & $1056(48.7 \%)$ & \\
\hline $\mathrm{N}$ & 417 & 4 & 43 & 1705 & 2169 & \\
\hline Age at order & & & & & & $<0.001^{2}$ \\
\hline Median & 63.6 & 68.1 & 63.4 & 57.1 & 58.9 & \\
\hline Mean (sd) & $61.3(18.8)$ & $65.9(6.7)$ & $61.4(14.4)$ & $51.6(26.2)$ & $53.7(25.1)$ & \\
\hline Q1, Q3 & $49.1,75.0$ & $64.8,69.2$ & $52.1,71.6$ & $33.6,72.0$ & $36.3,72.7$ & \\
\hline Range & $0.0-97.4$ & $56.0-71.1$ & $31.3-86.4$ & $0.0-120.3$ & $0.0-120.3$ & \\
\hline $\mathrm{N}$ & 417 & 4 & 43 & 1705 & 2169 & \\
\hline Age group (y) & & & & & & $<0.001^{3}$ \\
\hline $0-19$ & $4(1.0 \%)$ & $0(0.0 \%)$ & $0(0.0 \%)$ & $238(14.0 \%)$ & $242(11.2 \%)$ & \\
\hline $20-44$ & $85(20.4 \%)$ & $0(0.0 \%)$ & $7(16.3 \%)$ & $401(23.5 \%)$ & $493(22.7 \%)$ & \\
\hline $45-54$ & $47(11.3 \%)$ & $0(0.0 \%)$ & $7(16.3 \%)$ & $172(10.1 \%)$ & $226(10.4 \%)$ & \\
\hline $55-64$ & $84(20.1 \%)$ & $1(25.0 \%)$ & $12(27.9 \%)$ & 248 (14.5\%) & 345 (15.9\%) & \\
\hline $65-74$ & $93(22.3 \%)$ & $3(75.0 \%)$ & $8(18.6 \%)$ & $301(17.7 \%)$ & 405 (18.7\%) & \\
\hline $75-84$ & $61(14.6 \%)$ & $0(0.0 \%)$ & 7 (16.3\%) & $221(13.0 \%)$ & $289(13.3 \%)$ & \\
\hline$>=85$ & $43(10.3 \%)$ & $0(0.0 \%)$ & $2(4.7 \%)$ & $124(7.3 \%)$ & $169(7.8 \%)$ & \\
\hline $\mathrm{N}$ & 417 & 4 & 43 & 1705 & 2169 & \\
\hline \multicolumn{7}{|l|}{ Ethnicity } \\
\hline $\begin{array}{l}\text { Hispanic / } \\
\text { Latino }\end{array}$ & $23(41.1 \%)$ & 0 & $1(100.0 \%)$ & $25(28.4 \%)$ & $49(33.8 \%)$ & \\
\hline $\begin{array}{l}\text { Not Hispanic/ } \\
\text { Latino }\end{array}$ & $22(39.3 \%)$ & 0 & $0(0.0 \%)$ & $44(50.0 \%)$ & $66(45.5 \%)$ & \\
\hline Not Specified & $11(19.6 \%)$ & 0 & $0(0.0 \%)$ & $19(21.6 \%)$ & $30(20.7 \%)$ & \\
\hline $\mathrm{N}$ & 56 & 0 & 1 & 88 & 145 & \\
\hline Race & & & & & & $0.085^{1}$ \\
\hline Asian & $30(7.2 \%)$ & $1(25.0 \%)$ & $1(2.3 \%)$ & $120(7.0 \%)$ & $152(7.0 \%)$ & \\
\hline $\begin{array}{l}\text { Black or } \\
\text { African } \\
\text { American }\end{array}$ & $88(21.1 \%)$ & $1(25.0 \%)$ & $9(20.9 \%)$ & $295(17.3 \%)$ & $393(18.1 \%)$ & \\
\hline Caucasian & $94(22.5 \%)$ & $0(0.0 \%)$ & $10(23.3 \%)$ & $530(31.1 \%)$ & $634(29.2 \%)$ & \\
\hline Declined & $49(11.8 \%)$ & $0(0.0 \%)$ & $7(16.3 \%)$ & 245 (14.4\%) & $301(13.9 \%)$ & \\
\hline Other & $86(20.6 \%)$ & $1(25.0 \%)$ & $11(25.6 \%)$ & $279(16.4 \%)$ & 377 (17.4\%) & \\
\hline Pacific Islander & $1(0.2 \%)$ & $0(0.0 \%)$ & $0(0.0 \%)$ & $4(0.2 \%)$ & $5(0.2 \%)$ & \\
\hline Unavailable & $69(16.5 \%)$ & $1(25.0 \%)$ & $5(11.6 \%)$ & 232 (13.6\%) & 307 (14.2\%) & \\
\hline $\mathrm{N}$ & 417 & 4 & 43 & 1705 & 2169 & \\
\hline
\end{tabular}




\begin{tabular}{|c|c|c|c|c|c|c|}
\hline & $\begin{array}{l}\text { Neg2pos } \\
(\mathrm{N}=417)\end{array}$ & $\begin{array}{r}\text { Pos2neg } \\
(\mathrm{N}=4)\end{array}$ & $\begin{array}{l}\text { Unchanged } \\
\text { ind }(\mathrm{N}=43)\end{array}$ & $\begin{array}{r}\text { Unchanged neg } \\
(\mathrm{N}=1705)\end{array}$ & $\begin{array}{r}\text { Total } \\
(\mathrm{N}=2169) \\
\end{array}$ & $\mathrm{p}$ value \\
\hline \multicolumn{7}{|c|}{ Highest level of care } \\
\hline Admitted & $30(53.6 \%)$ & 0 & $1(100.0 \%)$ & $43(50.0 \%)$ & $74(51.7 \%)$ & \\
\hline $\begin{array}{l}\text { Discharged from } \\
\text { ED }\end{array}$ & $2(3.6 \%)$ & 0 & $0(0.0 \%)$ & $3(3.5 \%)$ & $5(3.5 \%)$ & \\
\hline ICU-level Care & $10(17.9 \%)$ & 0 & $0(0.0 \%)$ & $23(26.7 \%)$ & $33(23.1 \%)$ & \\
\hline Outpatient & $14(25.0 \%)$ & 0 & $0(0.0 \%)$ & $17(19.8 \%)$ & $31(21.7 \%)$ & \\
\hline $\mathrm{N}$ & 56 & 0 & 1 & 86 & 143 & \\
\hline \multicolumn{6}{|c|}{ Encounter type at order } & $<0.001^{1}$ \\
\hline Emergency & $84(20.1 \%)$ & $0(0.0 \%)$ & $3(7.0 \%)$ & $161(9.4 \%)$ & 248 (11.4\%) & \\
\hline Inpatient & $228(54.7 \%)$ & $4(100.0 \%)$ & $26(60.5 \%)$ & $1130(66.3 \%)$ & $1388(64.0 \%)$ & \\
\hline Outpatient & 105 (25.2\%) & $0(0.0 \%)$ & $14(32.6 \%)$ & $414(24.3 \%)$ & $533(24.6 \%)$ & \\
\hline $\mathrm{N}$ & 417 & 4 & 43 & 1705 & 2169 & \\
\hline \multicolumn{6}{|l|}{ Location at order } & $<0.001^{1}$ \\
\hline Allen Hospital & $38(9.1 \%)$ & $0(0.0 \%)$ & $4(9.3 \%)$ & $67(3.9 \%)$ & $109(5.0 \%)$ & \\
\hline Columbia & 178 (42.7\%) & $1(25.0 \%)$ & $21(48.8 \%)$ & $731(42.9 \%)$ & $931(42.9 \%)$ & \\
\hline $\begin{array}{l}\text { Columbia } \\
\text { Outreach }\end{array}$ & $16(3.8 \%)$ & $0(0.0 \%)$ & $1(2.3 \%)$ & $39(2.3 \%)$ & $56(2.6 \%)$ & \\
\hline $\begin{array}{l}\text { Lower } \\
\text { Manhattan }\end{array}$ & $11(2.6 \%)$ & $1(25.0 \%)$ & $3(7.0 \%)$ & $86(5.0 \%)$ & $101(4.7 \%)$ & \\
\hline Queens & $100(24.0 \%)$ & $0(0.0 \%)$ & $1(2.3 \%)$ & $223(13.1 \%)$ & 324 (14.9\%) & \\
\hline Weill Cornell & $69(16.5 \%)$ & $2(50.0 \%)$ & $12(27.9 \%)$ & $524(30.7 \%)$ & $607(28.0 \%)$ & \\
\hline Westchester & $5(1.2 \%)$ & $0(0.0 \%)$ & $1(2.3 \%)$ & $35(2.1 \%)$ & $41(1.9 \%)$ & \\
\hline $\mathrm{N}$ & 417 & 4 & 43 & 1705 & 2169 & \\
\hline \multicolumn{7}{|c|}{ Number of admissions } \\
\hline Median & 1.0 & NA & 1.0 & 1.0 & 1.0 & \\
\hline Mean (sd) & $1.0(0.8)$ & NA & $1.0(\mathrm{NA})$ & $0.9(0.6)$ & $1.0(0.7)$ & \\
\hline Q1, Q3 & $0.0,2.0$ & NA & $1.0,1.0$ & $0.8,1.0$ & $0.0,1.0$ & \\
\hline Range & $0.0-2.0$ & NA & $1.0-1.0$ & $0.0-2.0$ & $0.0-2.0$ & \\
\hline $\mathrm{N}$ & 56 & 0 & 1 & 88 & 145 & \\
\hline \multicolumn{7}{|c|}{ Admission duration (d) } \\
\hline Median & 5.6 & NA & 2.9 & 7.4 & 7.2 & \\
\hline Mean (sd) & $8.5(8.1)$ & NA & 2.9 (NA) & $13.2(15.6)$ & $11.3(13.3)$ & \\
\hline Q1, Q3 & $1.4,11.9$ & NA & $2.9,2.9$ & $1.5,18.4$ & $1.5,15.4$ & \\
\hline Range & $0.2-33.0$ & NA & $2.9-2.9$ & $0.0-83.5$ & $0.0-83.5$ & \\
\hline $\mathrm{N}$ & 56 & 0 & 1 & 88 & 145 & \\
\hline \multicolumn{7}{|c|}{ Admission 1 to test 1 (d) } \\
\hline Median & 8.5 & NA & 1.6 & 13.2 & 9.5 & \\
\hline Mean (sd) & $12.1(11.7)$ & NA & $1.6(\mathrm{NA})$ & $17.5(16.0)$ & $15.3(14.7)$ & \\
\hline Q1, Q3 & $3.5,20.3$ & NA & $1.6,1.6$ & $3.3,29.0$ & $3.4,25.7$ & \\
\hline
\end{tabular}




\begin{tabular}{lrrrrrr}
\hline & $\begin{array}{r}\text { Neg2pos } \\
(\mathrm{N}=417)\end{array}$ & $\begin{array}{r}\text { Pos2neg } \\
(\mathrm{N}=4)\end{array}$ & $\begin{array}{r}\text { Unchanged } \\
\text { ind }(\mathrm{N}=43)\end{array}$ & $\begin{array}{r}\text { Unchanged neg } \\
(\mathrm{N}=1705)\end{array}$ & $\begin{array}{r}\text { Total } \\
(\mathrm{N}=2169)\end{array}$ & $\mathrm{p}$ value \\
\hline Range & $0.5-42.9$ & $\mathrm{NA}$ & $1.6-1.6$ & $0.1-74.1$ & $0.1-74.1$ & \\
$\mathrm{~N}$ & 56 & 0 & 1 & 87 & 144 &
\end{tabular}

\section{Admission 2 to test 1 (d)}

Median

Mean (sd)

Q1, Q3

Range

$\mathrm{N}$

\section{Primary Outcome}

Deceased/

Discharged to

Hospice

Discharged (not

death)

Intubated (still

admitted)

Still admitted

(not intubated)

$\mathrm{N}$

\section{Deceased}

No

51 (91.1\%)

$5(8.9 \%)$

56

$\mathrm{N}$

0.2

$0.4(0.9)$

$0.1,0.4$

$-3.8-2.0$

33

$$
7 \text { (12.5\%) }
$$

$43(76.8 \%)$

$3(5.4 \%)$

$3(5.4 \%)$

56

\section{Symptomatic}

No

1 (3.8\%)

Unknown

1 (3.8\%)

Yes

24 (92.3\%)

$\mathrm{N}$
NA

NA

NA

NA

0

0

$0(0.0 \%)$

$1(100.0 \%)$

$0(0.0 \%)$

$0(0.0 \%)$

1

$1(100.0 \%)$

$0(0.0 \%)$

1

$0(0.0 \%)$

$0(0.0 \%)$

$1(100.0 \%)$

1
1.2

4.7 (8.0)

$0.2,4.1$

$0.0-33.0$

29

$9(10.2 \%)$

$16(11.0 \%)$

$68(77.3 \%) \quad 112(77.2 \%)$

$1(1.1 \%)$

$4(2.8 \%)$

$10(11.4 \%)$

$13(9.0 \%)$

88

145

$$
\begin{array}{rr}
81(92.0 \%) & 133(91.7 \%) \\
7(8.0 \%) & 12(8.3 \%) \\
88 & 145
\end{array}
$$

$0(0.0 \%)$

$1(3.4 \%)$

$1(50.0 \%)$

$2(6.9 \%)$

$1(50.0 \%)$

$26(89.7 \%)$

29

\section{Symptoms start to death (d)}

Median

Mean (sd)

Q1, Q3

Range

$\mathrm{N}$

\section{Any fever}

No

Yes

$\mathrm{N}$

$6(24.0 \%)$

$19(76.0 \%)$

25
18.5

18.5 (10.7)

$14.7,22.3$

$10.9-26.1$

2
NA

NA

NA

NA

0
NA

NA

NA

NA

0
18.5

NA $\quad 18.5(10.7)$

NA $14.7,22.3$

NA $\quad 10.9-26.1$

0

2

\section{Intubated}

No

$49(87.5 \%)$

$0(0.0 \%)$

$0(0.0 \%)$

$6(22.2 \%)$

$1(100.0 \%)$

$1(100.0 \%)$

$21(77.8 \%)$

0

1

1

27

$0 \quad 1(100.0 \%)$

$71(80.7 \%)$

$121(83.4 \%)$ 


\begin{tabular}{|c|c|c|c|c|c|c|}
\hline & $\begin{array}{l}\text { Neg2pos } \\
(\mathrm{N}=417)\end{array}$ & $\begin{array}{r}\text { Pos2neg } \\
(\mathrm{N}=4)\end{array}$ & $\begin{array}{l}\text { Unchanged } \\
\text { ind }(\mathrm{N}=43)\end{array}$ & $\begin{array}{r}\text { Unchanged neg } \\
(\mathrm{N}=1705)\end{array}$ & $\begin{array}{r}\text { Total } \\
(\mathrm{N}=2169)\end{array}$ & $\mathrm{p}$ value \\
\hline Yes & 7 (12.5\%) & 0 & $0(0.0 \%)$ & 17 (19.3\%) & 24 (16.6\%) & \\
\hline $\mathrm{N}$ & 56 & 0 & 1 & 88 & 145 & \\
\hline \multicolumn{7}{|l|}{ Extubated } \\
\hline No & $54(96.4 \%)$ & 0 & $1(100.0 \%)$ & $75(85.2 \%)$ & $130(89.7 \%)$ & \\
\hline Yes & $2(3.6 \%)$ & 0 & $0(0.0 \%)$ & $13(14.8 \%)$ & 15 (10.3\%) & \\
\hline $\mathrm{N}$ & 56 & 0 & 1 & 88 & 145 & \\
\hline \multicolumn{7}{|c|}{ Symptoms start to intubation (d) } \\
\hline Median & 11.0 & NA & NA & 7.0 & 10.5 & \\
\hline Mean (sd) & $14.4(11.5)$ & NA & NA & $7.0(\mathrm{NA})$ & $13.2(10.7)$ & \\
\hline Q1, Q3 & $10.0,21.0$ & NA & NA & $7.0,7.0$ & $7.8,18.5$ & \\
\hline Range & $0.0-30.0$ & NA & NA & $7.0-7.0$ & $0.0-30.0$ & \\
\hline $\mathrm{N}$ & 5 & 0 & 0 & 1 & 6 & \\
\hline \multicolumn{7}{|c|}{ Intubation duration (d) } \\
\hline Median & 3.5 & NA & NA & 3.0 & 3.0 & \\
\hline Mean (sd) & $3.5(3.5)$ & NA & NA & $5.0(5.6)$ & $4.8(5.2)$ & \\
\hline Q1, Q3 & $2.2,4.8$ & NA & NA & $2.0,5.0$ & $2.0,5.0$ & \\
\hline Range & $1.0-6.0$ & NA & NA & $1.0-20.0$ & $1.0-20.0$ & \\
\hline $\mathrm{N}$ & 2 & 0 & 0 & 12 & 14 & \\
\hline \multicolumn{7}{|l|}{ Decompensated } \\
\hline No & $46(82.1 \%)$ & 0 & $1(100.0 \%)$ & $68(77.3 \%)$ & $115(79.3 \%)$ & \\
\hline Yes & $10(17.9 \%)$ & 0 & $0(0.0 \%)$ & $20(22.7 \%)$ & $30(20.7 \%)$ & \\
\hline $\mathrm{N}$ & 56 & 0 & 1 & 88 & 145 & \\
\hline \multicolumn{7}{|c|}{ Symptoms start to decompensation (d) } \\
\hline Median & 16.0 & NA & NA & 7.0 & 11.0 & \\
\hline Mean (sd) & $16.3(11.3)$ & NA & NA & $7.0(\mathrm{NA})$ & $15.0(10.9)$ & \\
\hline Q1, Q3 & $10.2,24.7$ & NA & NA & $7.0,7.0$ & $8.5,23.5$ & \\
\hline Range & $0.0-30.0$ & NA & NA & $7.0-7.0$ & $0.0-30.0$ & \\
\hline $\mathrm{N}$ & 6 & 0 & 0 & 1 & 7 & \\
\hline \multicolumn{7}{|c|}{ Symptoms start to first test (d) } \\
\hline Median & 3.6 & NA & 9.1 & 4.4 & 4.4 & \\
\hline Mean (sd) & $5.0(5.2)$ & NA & $9.1(\mathrm{NA})$ & $4.4(\mathrm{NA})$ & $5.1(5.1)$ & \\
\hline Q1, Q3 & $1.3,7.8$ & NA & $9.1,9.1$ & $4.4,4.4$ & $1.6,7.9$ & \\
\hline Range & $-4.3-15.9$ & NA & $9.1-9.1$ & $4.4-4.4$ & $-4.3-15.9$ & \\
\hline $\mathrm{N}$ & 25 & 0 & 1 & 1 & 27 & \\
\hline Number of tests & & & & & & $0.009^{2}$ \\
\hline Median & 2.0 & 3.5 & 2.0 & 2.0 & 2.0 & \\
\hline Mean (sd) & $2.4(0.8)$ & $3.5(0.6)$ & $2.3(0.6)$ & $2.5(0.9)$ & $2.5(0.9)$ & \\
\hline Q1, Q3 & $2.0,3.0$ & $3.0,4.0$ & $2.0,2.0$ & $2.0,3.0$ & $2.0,3.0$ & \\
\hline
\end{tabular}


medRxiv preprint doi: https://doi.org/10.1101/2020.05.06.20093575; this version posted May 8, 2020. The copyright holder for this preprint (which was not certified by peer review) is the author/funder, who has granted medRxiv a license to display the preprint in perpetuity.

All rights reserved. No reuse allowed without permission.

\begin{tabular}{lrrrrr}
\hline & $\begin{array}{r}\text { Neg2pos } \\
(\mathrm{N}=417)\end{array}$ & $\begin{array}{r}\text { Pos2neg } \\
(\mathrm{N}=4)\end{array}$ & $\begin{array}{r}\text { Unchanged } \\
\text { ind (N=43) }\end{array}$ & $\begin{array}{r}\text { Unchanged neg } \\
(\mathrm{N}=1705)\end{array}$ & $\begin{array}{r}\text { Total } \\
(\mathrm{N}=2169)\end{array}$ \\
\hline Range & $2.0-9.0$ & $3.0-4.0$ & $2.0-5.0$ & $2.0-8.0$ & $2.0-9.0$ \\
$\mathrm{~N}$ & 417 & 4 & 43 & 1705 & 2169 \\
Number of positive results per patient & & & & \\
Median & 1.0 & 1.0 & 1.0 & 0.0 & 0.0 \\
Mean (sd) & $1.1(0.3)$ & $1.0(0.0)$ & $1.1(0.6)$ & $0.0(0.0)$ & $0.2(0.5)$ \\
Q1, Q3 & $1.0,1.0$ & $1.0,1.0$ & $1.0,1.0$ & $0.0,0.0$ & $0.0,0.0$ \\
Range & $1.0-3.0$ & $1.0-1.0$ & $1.0-4.0$ & $0.0-0.0$ & $0.0-4.0$ \\
$\mathrm{~N}$ & 417 & 4 & 43 & 1705 & 2169
\end{tabular}

1. Pearson's Chi-squared test (adjusted for multiple comparisons)

2. Linear Model ANOVA (adjusted for multiple comparisons)

3. Trend test for ordinal variables (adjusted for multiple comparisons) 